\section{幽闹 Digital Commons@}

Loyola Marymount University

LMU Loyola Law School
Loyola of Los Angeles International and Comparative Law Review

$6-1-2003$

\title{
The Surrender of War Criminals to the International Criminal Court
}

Goran Sluiter

Follow this and additional works at: https://digitalcommons.Imu.edu/ilr

Part of the Law Commons

\section{Recommended Citation}

Goran Sluiter, The Surrender of War Criminals to the International Criminal Court, 25 Loy. L.A. Int'I \& Comp. L. Rev. 605 (2003).

Available at: https://digitalcommons.Imu.edu/ilr/vol25/iss3/8

This Article is brought to you for free and open access by the Law Reviews at Digital Commons @ Loyola Marymount University and Loyola Law School. It has been accepted for inclusion in Loyola of Los Angeles International and Comparative Law Review by an authorized administrator of Digital Commons@Loyola Marymount University and Loyola Law School. For more information, please contact digitalcommons@lmu.edu. 


\title{
The Surrender of War Criminals to the International Criminal Court
}

\author{
DR. GÖRAN SLUITER ${ }^{*}$
}

\section{INTRODUCTION}

On July 1, 2002, the Treaty of Rome established a permanent court called the International Criminal court (ICC). ${ }^{1}$ The ICC has jurisdiction over war crimes, crimes against humanity, and genocide. Legal commentators are anticipating an extension of the ICC's jurisdiction to include the prosecution of crimes of aggression. Like any other international criminal tribunal or international organisation, the ICC can only fulfill this mandate when it receives the necessary assistance from cooperating states. The comparison of former Yugoslavia's International Criminal Tribunal (ICTY) to "a giant without arms and legs" who "needs artificial limbs to walk and work" is applicable to the ICC. ${ }^{2}$ Like the ICTY and the International Criminal Tribunal for Rwanda (ICTR), the ICC must rely on the individual or collective efforts of states to assist the ICC in a variety of ways. States' assistance with

* Lecturer in international law, Utrecht University and Judge at the Utrecht District Court.

1. Rome Statute of the International Criminal Court, U.N. GAOR, U.N. Doc. A/CONF.183/9 (1998) (entered into force July 1, 2002) [hereinafter ICC Statute]. According to Article 126 of the ICC Statute, the "Statute shall enter into force on the first day of the month after the 60th day following the date of the deposit of the 60th instrument of ratification, acceptance, approval, or accession with the Secretary-General of the United Nations." ICC Statute at 87. On April 11, 2002, a special U.N. ceremony was held wherein ten states simultaneously ratified the ICC Statute, thereby increasing the number of ratifying states to sixty. Information regarding the special U.N. signing ceremony is available at http://www.un.org/law/icc/general/public.htm (last visited Sept. 21, 2003).

2. Antonio Cassese, On the Current Trends Towards Criminal Prosecution and Punishment of Breaches of International Humanitarian Law, 9 EUR. J. INT'L L. 2, 13 (1998). 
the arrest and surrender of war criminals has received the most attention because of the important consequences these acts have on these individuals. The ICC Statute's requirement that the accused be present for the trial to commence underlines the importance of states to assist with the state's arrest and surrender. ${ }^{3}$ The invasive nature of their surrender deprives individuals of liberty and exposes them to a foreign criminal justice system. Thus, arrest and surrender raise issues of efficacy and expediency on the one hand, and individual rights on the other.

This Article analyzes the efficacy and expediency of the ICC's surrender regime and its impact on individual rights. In particular, it addresses the scope of the obligation incumbent upon states to provide assistance in arrests that result in effective and expedient surrenders, and to what extent the surrender regime protects war criminals' human rights. A discussion of these issues requires a systematic analysis of the substantive and procedural elements of the ICC surrender regime. In order to fully understand and distinguish the particularities of the ICC surrender regime from extradition law, some knowledge of the overall cooperative relationships between states and the ICC is required.

Part II compares some key elements of the ICC cooperation regime with interstate, ICTY, and ICTR legal assistance regimes. Parts III and IV analyze the surrender proceedings at the ICC and national levels. Part $\mathrm{V}$ analyzes the duty to surrender as provided in the ICC Statute, and whether the grounds for refusing ICC surrender requests includes traditional extradition. Part VI

3. Article 63 of the ICC Statute provides that the accused shall be present during the trial, although the accused may be removed from the courtroom in exceptional circumstances. (e.g., the accused, if present in the courtroom, disrupts the proceedings). ICC Statute, supra note 1, at 48; see William A. Schabas, Article 63: Trial in the Presence of the Accused, in COMMENTARY ON THE ROME STATUTE OF THE INTERNATIONAL CRIMINAl COURT: OBSERVERS' NOTES, ARTICle BY ARTICle, supra note 3, at 803-08. Article 61 provides prior to the commencement of trial, a hearing to confirm the charges must be held. ICC Statute, supra note 1, at 46 . This hearing can be held in the absence of the accused after he has waived his right to be present, has fled, or cannot be found. Id. After the hearing, the Pre-Trial Chamber shall determine whether there is sufficient evidence to establish substantial grounds to believe that the person committed each of the crimes charged. Id. This procedure is similar to the hearing that is conducted in the absence of the accused provided for in Rule 61 of the Rules of Procedure and Evidence (RPE) of the ICTY and ICTR. JOHN R.W.D JONES, THE PRACTICE OF THE INTERNATIONAL CRIMINAL TRIBUNALS FOR THE FORMER YUGOSLAVIA AND RWANDA 304, 588 (2d ed. 2000) [hereinafter ICTY AND ICTR RULES]. Both the Article 61 hearing and the Rule 61 hearing, however, are not equal to a trial, because the accused's guilt is not decided. ICC Statute, supra note 1, at 46; ICTY AND ICTR RULES at 304, 588. 
discusses the ICC surrender regime in the context of international human rights law, and addresses the potential conflict between the ICC surrender regime and states' existing obligations under international human rights treaties.

\section{ARrest AND SurRender AS PART OF THE ICC LEGAL ASSISTANCE REGIME}

\section{A. Extradition and Surrender: Not Merely a Question of Terminology}

Article 102 of the ICC Statute defines both surrender and extradition. ${ }^{4}$ Both concepts refer to a state's transfer of a person to another criminal jurisdiction. ${ }^{5}$ The vital distinction between the two is that surrender applies to the ICC, and extradition refers to the prosecution or the enforcement of an individual's sentence in another state. The purpose of this distinction is to ensure that traditional extradition law is not applicable, mutatis mutandis, to the special surrender regime. ${ }^{6}$ The application of traditional

4. ICC Statute, supra note 1 , at 77 . The provision reads as follows:

For the purposes of this Statute:

(a) "surrender" means the delivering up of a person by a state to the Court, pursuant to this Statute.

(b) "extradition" means the delivering up of a person by one State to another as provided by treaty, convention, or national legislation.

5. Id. The definitions in Article 102 are silent as to the purpose of delivering up a person. Arguably, the purposes of surrender and extradition are to prosecute the requested person or to enforce a sentence. Traditionally, this is a part of the definition of extradition provided in various extradition treaties. See, e.g., European Convention on Extradition, Dec. 13, 1957, art. 1, Europ. T.S. No. 24 [hereinafter European Convention]; U.N. Model Treaty on Extradition, G.A. Res. 45/116, U.N. GAOR, 3d Comm., 45th Sess., at 4, U.N. Doc. A/RES/45/116 (1991) [hereinafter U.N. Model Treaty]. Extradition and surrender are distinguishable from delivering up a person for other purposes, such as giving testimony. Thus, transferring a detained witness for the purpose of giving testimony does not fall within the realm of surrender or extradition. This clearly follows from Article 93(7) regarding the interstate cooperation context where the transfer of detained witnesses is not part of the extradition law, but treaties on other forms of mutual assistance in criminal matters. See, e.g., European Convention on Mutual Assistance in Criminal Matters, Apr. 20, 1959, art. 11, Europ. T.S. No. 30. The definition of surrender in Article 102 includes these other forms of delivering up a person provided for in Article 93(7), therefore adding to the confusion in the terminology. ICC Statute, supra note 1, at 75,77 .

6. There are instances where persons are delivered up to other states for the purpose of prosecution that are outside the realm of extradition. For example, under the Status of Forces agreements, states that send troops practically exercise exclusive jurisdiction over those soldiers. When they exercise their jurisdiction, the receiving state has a duty to hand 
extradition law creates a number of obstacles to the effective and expeditious capture of war criminals. For this reason, the ICTY and ICTR statutes and rules consistently avoid the term "extradition," and instead use the word "transfer" or "surrender."7

During the ICC Statute negotiations, the debate over the terms "surrender" or "extradition" symbolized the delegates' divergent views regarding the nature of the ICC surrender or extradition regime. A few delegates strongly adhered to the use of the term extradition, because "their national laws pertaining to extradition prohibit them from handing over their nationals to the court, and the use of 'extradition' would support their national positions." In the end a "use of terms" provision was adopted as a compromise to accommodate the few states whose positions were "that they do not consent to extradite nationals in general but only accept such an obligation in the very specific context of the court."

The drafting history illustrates that the distinction between surrender and extradition was not simply about terminology and "legal sophistry." 10 The entire ICC legal assistance law, in addition to the ICC surrender regime, aspired to base itself on different

over the requested person. See Agreement (with appendix) Between the Parties to the North Atlantic Treaty Regarding the Status of Their Forces, June 19, 1951, art. 7(5), 199 U.N.T.S. 78 [hereinafter North Atlantic Treaty].

7. See Statute of the International Criminal Tribunal for Rwanda, U.N. SCOR, 3453rd mtg. at 7-8, 10, U.N. Doc. S/RES/955 (1994), available at http://wwics.si.edu/ subsites/ccpdc/pubs/addm/rwan.htm (last visited Sept. 21, 2003) [hereinafter ICTR Statute]; Statute of the International Tribunal, U.N. SCOR, at 5, 7, U.N. Doc. S/RES/827 (1993), available at http://www.un.org/icty/basic/statut/statute.htm (last visited Sept. 21, 2003) [hereinafter ICTY Statute]. Rules 55-61 of both Tribunals deal with arrest and transfer or surrender and contain various references to transfer or surrender. See ICTY AND ICTR RuLES, supra note 3, at 215, 541. The ICTY Statute and ICTR Rules use the terms 'surrender' and 'transfer' interchangeably and there are no legal differences between the two. See Bert Swart, Arrest and Surrender, in 2 THE Rome StatuTE OF THE INTERNATIONAL CRIMINAL COURT: A COMMENTARY 1639, 1678 (Antonio Cassese et al. eds., 2002). For the sake of consistency, the choice of either term in the Statutes and Rules would have been preferable.

8. Phakiso Mochochoko, International Cooperation and Judicial Assistance, in THE INTERNATIONAL CRIMINAL COURT: THE MAKING OF THE ROME STATUTE: ISSUES, Negotiations, Results 305, 309 (Roy S. Lee ed., 1999); see Claus Kress, Article 102: Use of Terms, in COMMENTARY ON THE ROME STATUTE OF THE INTERNATIONAL CRIMINAL COURT: OBSERVERS' NOTES, ARTICLE BY ARTICLE, supra note 3, at 1157-58.

9. Kress, supra note 8 , at 1157.

10. WILliam A. SCHABAS, AN INTRODUCTION TO THE INTERNATIONAL CRIMINAL COURT 111 (2001). 
principles and content when compared to traditional cooperation models between sovereign states."

\section{B. Legal Bases Underlying the Duty to Provide Legal Assistance}

Distinguishing different regimes depends on the legal basis underlying the applicable assistance provision that results in three possible situations. First, party states are governed by the legal assistance provision in the ICC Statute. Parties to the ICC cooperation regime must perform their duties under the Statute in good faith. ${ }^{12}$ Because Article 120 of the ICC Statute prohibits states from including certain reservations upon their ratification of the Statute, the obligations apply identically to all party states. ${ }^{13}$

Second, the fundamental rule of pacta tertiis nec nocent nec prosunt prevents the ICC Statute from creating a legal basis that requires nonparty states to provide assistance to the ICC. ${ }^{14}$ Nonparty states, however, can provide assistance on a voluntary basis, and may have a duty to provide assistance in two scenarios. First, Article 12(3) of the ICC Statute provides that a nonparty state may accept the ICC's jurisdiction on an ad hoc basis. The voluntary acceptance of the ICC's jurisdiction requires a nonparty state's unconditional acceptance of all cooperation obligations under the Statute. ${ }^{15}$ Second, Article $87(5)$ provides that a nonparty state can provide assistance through ad hoc cooperation agreements with the ICC. Although the content of such future agreements is often speculative, the ICC may base the content of

11. "[The] clear distinction at the terminological level should, as was the underlying thinking, at the same time contribute to a growing awareness on the national level for the substantial differences between horizontal and vertical cooperation." Kress, supra note 8, at 1157-58 (citing Preliminary Remarks, Part 9, margin No. 3).

12. Cf. Vienna Convention on the Law of Treaties, May 23, 1969 art. 26, 1155 U.N.T.S. 331 [hereinafter Vienna Convention].

13. The nuance in the application of this Statute is that states can issue certain declarations upon their ratification of the Statute, which have a legal affect on their obligations to provide legal assistance. Article 124 allows states to refuse the court's jurisdiction over war crimes for a period of seven years. ICC Statute, supra note 1, at 86. A declaration made under Article 124 undeniably reduces the state's duty to provide assistance. Pursuant to Article 87(2), a state's declaration of the language in which a request for assistance is made is far less drastic. ICC Statute, supra note 1, at 65.

14. Vienna Convention, supra note 12 , at art. 34.

15. ICC Statute, supra note, 1 . Whether it was a wise solution to link the acceptance of jurisdiction to the full acceptance of cooperation obligations is questionable. States may be sooner prepared to accept the court's jurisdiction thereby enabling the court to commence its investigations and prosecutions to the extent that this would not ipso facto impose a variety of unconditional cooperation obligations on the states. 
the ad hoc agreement on the ICC Statute's cooperation regime. The nonstate party, whose cooperation is needed, however, has a strong negotiation position. Therefore, the ICC faces the difficult choice between refusing a state's assistance or accepting the requested state's conditions in exchange for its assistance.

The third "cooperation regime" applies when the Security Council refers a situation to the ICC. According to Article 13 of the ICC Statute, the Security Council, acting under Chapter VII of the U.N. Charter, may trigger the jurisdiction of the ICC. The Security Council may accomplish this by referring a situation in which one or more of the crimes mentioned in Article 5 of the Statute are committed. ${ }^{16}$ In the future, when the Council triggers the ICC's jurisdiction, this resolution may also supplement the Statute's cooperation regime. The resolution can be used to obligate U.N. members to provide assistance to restore and maintain international peace and security. ${ }^{17}$

16. The possibility that the Security Council will refer "cases" to the court is recognized in the International Law Commission's draft statute for an International Criminal Court. See Report of the I.L.C. on the Work of Its Forty-Ninth Session, U.N. GAOR, 49th sess., Supp. No. 10, U.N. Doc. A/49/10, at 84 (1994) [hereinafter Report of the I.L.C.]. Within the compilation of proposals forming the basis for the negotiations in Rome, however, the possibility that the Security Council will submit cases to the court is only mentioned as an option. See Report of the Preparatory Committee on the Establishment of an International Criminal Court, U.N. Doc. A/CONF.183/2/Add.1, at 34 (1998) [hereinafter Report of the Preparatory Committee]. For background on the relationship between the court and the Security Council, see Lionel Yee, The International Criminal Court and The Security Council: Articles $13(b)$ and 16, in THE INTERNATIONAL CRiminal COURT: The Making of the Rome StatuTe: Issues, Negotiations, RESUlTs 143-52 (Roy S. Lee ed., 1999); Sir Franklin Berman, The Relationship Between the International Criminal Court and the Security Council, in HERMAN A. M. VON HEBEL ET AL., REFLECTIONS ON THE INTERNATIONAL CRIMINAL COURT: ESSAYS IN HONOUR OF ADRIAAN BOS 173-80 (Johan G. Lammers \& Jolien Schukking eds., 1999); Gabriëlle H. Oosthuizen, Some Preliminary Remarks on the Relationship Between the Envisaged International Criminal Court and the U.N. Security Council, 46 NETH. INT'L L. REV., 313, 313-42 (1999).

17. For more detail, see Göran SLUITER, INTERNATIONAL CRIMINAL ADJUDICATION AND THE COLLECTION OF EVIDENCE: OBLIGATIONS OF STATES 71-72 (2002), (distinguishing three possible scenarios where the Security Council may submit a case to the court in the area of legal assistance):

First of all, the Security Council may refer a situation, which it may describe in more detail, in a resolution to the court, without any further comments or details. In this [situation] the matter will be dealt with in accordance with the Statute and the duty to cooperate will be exclusively based on the Statute, meaning, for example, that states non-parties are under no obligation to assist the court.

A second, more likely, scenario [ ] is that a Chapter VII resolution submitting a matter to the court decides that all states - or all UN members - 
This Article illustrates that the applicable cooperation regime may vary. Which regime applies depends on the state whose assistance is sought, as well as on the manner in which the investigation has been triggered. Because the content of other cooperation regimes are too speculative, the following discussion only analyses the ICC Statute's cooperation and surrender regimes.

\section{The ICC: A Vertical Cooperation Regime?}

The distinctive features of the ICC, ICTY, and ICTR cooperation laws are best described in comparison to cooperation regimes that states have been familiar with for a long time. There are a number of common features to the interstate, or horizontal, legal assistance regimes. Similar to the debate between the use of the terms extradition or surrender, it is assumed that, like the ICTY and ICTR, the ICC is superior to the states. This assumption has resulted in the characterization of these cooperation models as "vertical" or "supranational."18 This hierarchical relationship is justified by the nature of the crimes

shall co-operate with the court in accordance with its Statute. The resolution, and ultimately the UN Charter, would then constitute the legal basis for the duty to co-operate for all UN members. The duty to co-operate would, for states that are members of the United Nations but not parties to the Statute, be confined to the investigation submitted to the court by the Council. The scope of the duty to co-operate would not differ from that incumbent on state parties in case of an investigation triggered by a state or initiated by the Prosecutor. As a result, the grounds of refusal set out in the Statute are applicable to and can be invoked by the states non-parties.

The third and final option is that the Security Council, with a view to restoring international peace and security, decides that UN members should have the obligation to cooperate fully with the court. To be more specific, the Council could decide that (certain of) the grounds for refusal in the ICC Statute are not applicable to UN members. This seems an unlikely situation because it requires that the Council shapes a new cooperation regime, which may be difficult to reconcile with the legal framework in which the court has to operate. Furthermore, this may be seen as an unauthorised interference with the application in practice of the Statute.

18. The concept horizontal and vertical legal assistance relationships was introduced by the ICTY Appeals Chamber in the Blaškic subpoena case, indicating the hierarchy between the jurisdiction of the ad hoc tribunals and the consequences of states providing legal assistance. See Prosecutor v. Tihomir Blaškic, Judgement on the Request of the Republic of Croatia for Review of the Decision of Trial Chamber II of 18 July 1997, Case No. IT-95-14-AR108bis, A. Ch., Oct. 29, 1997, para. 47, International Criminal Tribunal for the Former Yugoslavia, http://www.un.org/icty/blaskic/appeal/decision-e/ 71029JT3.html (last visited Sept. 21, 2003). 
within the ICC's jurisdiction and the international community's participation and support of these endeavors. Nevertheless, understanding the meaning of this "verticalism" and whether the ICC really fits this description, when compared to the ICTY and ICTR cooperation regimes, is still questionable. Three important distinctive characteristics of the ICC cooperation regime must be discussed to provide the answers.

\section{Grounds for Refusal}

Traditional extradition treaties generally contain a variety of grounds on which the requested state may or must refuse to assist another state. ${ }^{19}$ As a result, the extent of the obligation to provide assistance to another state is generally quite limited. ${ }^{20}$

In a vertical cooperation relationship, whereby a supranational criminal tribunal requests assistance, the grounds for refusal of the interstate legal assistance treaties are not applicable to the same degree as the grounds contained in the ICC, ICTY or ICTR cooperation regimes. The ICC surrender regime has done away with the bulk of the traditional grounds for refusal, such as the political offence exception, the double criminality requirement, and the refusal to extradite nationals. The ICC surrender regime, however, contains a few procedural and substantive grounds for refusal to surrender that the ICTY and ICTR laws do not provide. The strongest difference among these institutions is that the ICC does not benefit from a priority rule similar to that contained in Article 103 of the U.N. Charter. The ICC accommodates the concerns of states that have competing obligations under international law, including extradition treaties. ${ }^{21}$

19. Cf. European Convention, supra note 5; U.N. Model Treaty, supra note 5, at 3-7.

20. Generalizations, however, must be used carefully. Cooperative states, such as the European Union, may be prepared to engage in more far reaching forms of cooperation in criminal matters. An example is the inapplicability of a European arrest warrant to traditional extradition law. Commission Proposal for a Council Framework Decision on the European Arrest Warrant and the Surrender Procedures between the Member states, pmbl. (12) 2001 O.J. (C 332) 306.

21. See SLUITER, supra note 17, at 167-69; cf. Antonio Cassese, The Statute of the International Criminal Court: Some Preliminary Reflections, 10 EUR. J. INT'L L. 166 (1999). "[O]ne would have thought that the obligations stemming from the Rome Statute should have taken precedence over those flowing from other treaties." Id. 


\section{Reciprocity}

Generally, states are only prepared to provide legal assistance to another state if that state can be expected to reciprocate such legal assistance. ${ }^{22}$ The principle of reciprocity is derived from various legal assistance treaties. ${ }^{23}$ International criminal tribunals were created to prosecute only a limited number of crimes. Therefore, in principle, a state's assistance is given to the tribunals exclusively. This is not to say that in certain situations, the assistance of international criminal tribunals toward states is not welcomed. The concurrent jurisdiction of these tribunals, however, prevents these institutions from being able to prosecute all perpetrators.

The drafters of the Rome Statute acknowledged that the ICC's assistance toward a state may advance the prosecution of war criminals-a possibility that is provided for in the Statute. Article 93(10) of the ICC Statute authorizes the ICC to cooperate with, and provide assistance to, a party state that is prosecuting crimes within the ICC's jurisdiction or a serious crime under the requesting state's national law. The ICC has no duty to provide any assistance ${ }^{24}$ which makes it difficult to characterize a truly reciprocal and equally cooperative relationship between the ICC and the states. This lack of reciprocity is another distinctive feature of the ICC cooperation model.

Reciprocity poses additional problems in the context of surrender. Article 101's rule of specialty acts as an obstacle to prosecute an individual in any state other than where the individual was arrested. ${ }^{25}$

\section{Dispute Settlement}

If a dispute occurs regarding the extent of the duty to cooperate, the legal assistance relationship between states should

22. This is not to say that lack of reciprocity is always a material ground for refusing the requested assistance. See Heinrich Grützner, International Judicial Assistance and Cooperation in Criminal Matters, in M. CHERIF BASSIOUNI \& VED P. NANDA, 2 A TREATISE ON INTERNATIONAL CRIMINAL LAW: JURISDICTION AND COOPERATION 189, 230 (1973).

23. Cf., e.g., European Convention, supra note 5.

24. See Kimberly Prost \& Angelika Schlunck, Articles 93, in COMMENTARY ON THE Rome Statute of the International Criminal Court: Observers' Notes, ARTICLE BY ARTICLE, supra note 3, at 1117, 1117.

25. See discussion infra Part V.E for the rule of speciality as a condition to surrender. 
be settled through diplomatic means or third party adjudication. Although a considerable number of legal assistance treaties do not provide for compulsory settlement of disputes through these methods, states may still accept the International Court of Justice's (ICJ) jurisdiction to resolve the dispute. ${ }^{26}$ It is unthinkable that in a horizontal cooperation relationship, either the requesting or the requested side will resolve disputes regarding the duty to provide legal assistance.

There is a compulsory dispute settlement mechanism in a vertical cooperation relationship where a hierarchically superior international criminal tribunal is assisted. The task of settling disputes of the requesting party is the most fundamental deviation from the horizontal legal assistance model as it is most indicative of a legal assistance relationship based on hierarchy. Contrary to the statutes of the ad hoc tribunals, the ICC Statute explicitly regulates the settlement of disputes between states and the ICC. Article 119(1) of the ICC Statute provides that "[a]ny dispute concerning the judicial functions of the court shall be settled by the decision of the court."27

Any questions concerning the cooperation with, and legal assistance to, the ICC are part of the "judicial functions of the court." ${ }^{, 28}$ Article $87(7)$ confirms the ICC's power to issue judicial findings for disputes over the extent of the duty to cooperate. ${ }^{29}$

26. This is a distinction between conventions where legal assistance is only one element and conventions where legal assistance is the exclusive object. The first category includes those specialized U.N. Conventions combating organized crime and drug trafficking. These conventions provide for compulsory dispute settlement mechanisms, such as the International Court of Justice. States, however, may include reservations to relevant provisions. See United Nations Convention against Illicit Traffic in Narcotic Drugs and Psychotropic Substances (with annex), Dec. 20, 1988, art. 32(2), 1582 U.N.T.S. 165; United Nations Convention Against Transnational Organized Crime, U.N. GAOR, 55th Sess. Agenda Item 105, at 29, U.N. Doc. A/RES/55/25 (2001). For conventions that do not contain provisions related to dispute settlement, see European Convention, supra note 5; President's Message to Congress Transmitting Inter-American Convention on Mutual Assistance in Criminal Matters (Jan. 10, 1995); U.N. Model Treaty, supra note 5.

27. ICC Statute, supra note 1.

28. See Roger Clark, Article 119, in COMMENTARY ON THE ROME STATUTE OF THE INTERnATIONAL CRIMINAl COURT: OBSERVERS' NOTES, ARTIClE by ARTICLE, supra note 3 , at 1245 .

29. See Alain Pellet, Settlement of Disputes, in 2 THE RoME STATUTE OF THE InTERnational Criminal COURT: A COMmEnTARy 1843 (Antonio Cassese et al. eds., 2002) (concluding that Article 119, when read in conjunction with Article 87(7), "empowers the court to make findings on all questions relating to cooperation between states and the ICC"). 
Party states conceded to the ultimate interpretation of the extent of the duty to cooperate when they ratified the Statutes and accepted Article 119, in particular. This ratification included their concession to the interpretation of the duty to arrest and surrender war criminals to the requesting side, which is typically the ICC.

\section{Enforcement of the Duty to Cooperate}

The ICC cooperation regime succeeded in duplicating the "vertical model" of the ICTY and ICTR cooperation regimes. Although the cooperation model looks strong on paper, providing assistance to the ICC will depend on the availability of effective methods to enforce the state's duty to cooperate. Such enforcement mechanisms include the prosecutor or the party state's ability to trigger the duties of contracting parties regarding investigation and prosecution. ${ }^{30}$

Pursuant to Article $87(7)$ of the ICC Statute, a clear process exists for inducing a party state's compliance with a request for assistance. First, the ICC may make a judicial finding of noncompliance where a party state fails to comply with a request to cooperate with the ICC. A judicial finding of noncooperation is dual in character. It is an enforcement measure. As such, the impact of an impartial international judicial body establishing that a state has breached its obligations under an international treaty should not be underestimated. Such a finding, establishing a noncooperating state's illegal actions, may induce its compliance. Second, a judicial finding of noncompliance satisfies the vital prerequisite to submit the matter to those institutional bodies designated to enforce the Statute.

After a judicial finding of noncompliance, the ICC may refer the matter to the Assembly of States (Assembly). This process offers an end-run around the Prosecutor's direct submission of a state's noncompliance to the Assembly. ${ }^{31}$ Pursuant to Article

30. The enforcement of a duty to cooperate on the basis of an ad hoc cooperation agreement or following the referral of a situation by the Security Council is beyond the scope of this Article. For enforcement mechanisms in these situations, see Göran Sluiter, State Cooperation with the ICC, in TREATY ENFORCEMENT AND INTERNATIONAL COOPERATION IN CRIMINAL MATTERS: WiTH SPECIAL REFERENCE TO THE CHEMICAL WEAPONS CONVENTION 135-36 (Rodrigo Yepes-Enriquez \& Lisa Tabassi eds., 2002).

31. The approach adopted in Rule 7 bis (B) of the ICTY and ICTR gives the Prosecutor the option to report instances of non-compliance to the President, who may then report it to the Security Council. ICTY AND ICTR RULES, supra note 3, at 227, 545. 
112(2)(f), the Assembly may "consider pursuant to article 87, paragraphs 5 and 7 , any question relating to non-cooperation." The Statute's silence on the measures to impose on a state in breach of its obligation to cooperate is surprising, and calls into question the effectiveness of the Assembly's responses to violations of the duty to cooperate. This observation raises other inconsistencies among the states' other duties under the Statute. For example, if a party state fails to meet its obligations to finance the ICC, the Statute specifically provides that the state shall, depending on the extent of the breach, have no vote in the Assembly and in the Bureau. ${ }^{33}$ The ICC could also enforce similar measures when a state breaches its duty to provide legal assistance to the ICC.

\section{ISSUING REQUESTS FOR ARREST AND SURRENDER: THE INTERNAL PROCEDURE}

There are two elements of the ICC's internal procedure to request the surrender of an individual. First, the ICC's issuance of an arrest warrant is governed by Article 58. Second, the issuance of a surrender request is governed by Part 9 of the Statute.

\section{A. The Procedure of Article 58: Arrest}

\section{Competent Organ}

In the overwhelming majority of cases, national authorities must arrest the person before they surrender the person for the purpose of prosecution. ${ }^{34}$ Article 58 regulates the issuance of an arrest warrant. The Pre-Trial Chamber is designated to issue arrest warrants. ${ }^{35}$ Here, the Statute is consistent with international human rights instruments and the practice in many national

32. For more detail on the role of the Assembly of states Parties, see Adriaan Bos, Assembly of States Parties, in 2 THE ROME STATUTE OF THE INTERNATIONAL CRIMINAL COURT: A COMMENTARY 297-314 (Antonio Cassese et al. eds., 2002).

33. See ICC Statute, supra note 1, at 82-83.

34. Even when the individual is already detained, an arrest warrant by the ICC should be issued to ensure his continued detention in a form of constructive custody. Article $58(7)$ authorizes the issuance of a summons to appear when a summons is sufficient to ensure the person's appearance. ICC Statute, supra note 1, at 44.

35. For a more thorough analysis of the role and powers of the ICC Pre-Trial Chamber, see Olivier Fourmy, Powers of the Pre-Trial Chambers, in THE RoME STATUTE OF THE INTERNATIONAL CRIMINAL COURT: A COMMENTARY 1207-30 (Antonio Cassese et al. eds., 2002). 
criminal jurisdictions because judicial intervention is required to deprive a person of his or her liberty. ${ }^{36}$ In urgent situations, however, human rights law and common practice in domestic criminal jurisdictions permit prosecutorial or police authorities to arrest and detain an individual, but only under the condition that he or she is brought promptly before a judicial authority. ${ }^{37}$ Contrary to the ICC's legal framework, the ICTY and ICTR Rules of Procedure and Evidence (RPE) empower the prosecutor, in urgent situations, to directly request any state to arrest a suspect. ${ }^{38}$ The ICC framers did not believe similar powers were necessary because the delegation reached an agreement on the creation of a Pre-Trial Chamber that had various powers in the pre-trial phase. The Chamber included the power to issue arrest warrants. ${ }^{39}$ Pursuant to Article 58(1) of the Statute, the Pre-Trial Chamber issue's warrants based the prosecutor's application at any time after the initiation of an investigation. The language of Article 58(1) appears flexible enough to deal with urgent situations.

\section{Conditions for Issuance}

As in many national criminal jurisdictions, the conditions under which the Pre-Trial Chamber must issue an arrest warrant are twofold. First, the prosecutor must show there are "reasonable

36. That arrests in the absence of a warrant do not take place "in accordance with the law" and thus amount to arbitrary arrest is consistent with international human rights jurisprudence. See, e.g., Dimitry L. Gridin v. Russian Federation, Communication No. 770/1997, July 20, 2000, U.N. Doc. CCPR/C/69/D/770/1997, U.N. GAOR, 69th Sess., Supp. No. 40, Annex 9, at 172-77; see also U.N. Doc. A/55/40 (2000) (discussing the Human Rights Committee's supervision of the states' observance of the International Covenant of Civil and Political Rights).

37. Cf. Article 5(3) of the European Convention of Human Rights and Article 9 (3) of the International Covenant of Civil and Political Rights.

38. ICTY AND ICTR RULES, supra note 3, at 40. ICTY case law confirms that the power of the Prosecutor to request an individual's provisional arrest does not depend on the issuance of a previous arrest warrant. See Prosecutor v. Mucic, Decision on the Motions for the Exclusion of Evidence by the Accused, in ANNOTATED LEADING CASES of INTERNATIONAL CRIMINAL TRIBUNALS: THE INTERNATIONAL CRIMINAL TRIBUNAL FOR THE FORMER YUGOSLAVIA 1993-1998 227 (Andre Klip \& Goran Sluiter eds., 1999).

39. For the negotiation history and creation of the Pre-Trial Chamber, see Fabricio Guariglia, Investigation and Prosecution, in THE INTERNATIONAL CRIMINAL COURT: The Making of THE Rome StatuTe: Issues, Negotiations, Results 234-38 (Roy S. Lee ed., 1999). The ICTY and ICTR Statutes did not provide for pre-trial judicial involvement. In fact, an arrest warrant can only be issued by a Judge or Chamber after confirmation of the indictment. ICTY Statute, supra note 7, at 5; ICTR Stature, supra note 7 , at 7-8. 
grounds" to believe the person concerned committed a crime within the court's jurisdiction. ${ }^{40}$ Second, the person must be arrested for a specific purpose. ${ }^{41}$ The ICC Statute's conditions for the issuance of an arrest warrant are stricter than the ICTY and ICTR Statutes. The latter instruments, or the applicable RPE, do not contain the condition of necessity. ${ }^{42}$

As previously mentioned, pursuant to Article 58(1)(a), the Prosecutor must meet the burden of proving "reasonable grounds." It is unclear, and thus remains to be settled in future jurisprudence, whether this level lies below the criterion of a prima facie case, which is the standard provided for in Article 19(1) of the ICTY Statute and Article 18(1) of the ICTR Statute. ${ }^{43}$ Although the "reasonable grounds" standard is the minimum standard under Article 58, the actual standard applied by the PreTrial Chamber, however, may be more demanding, depending on where the arrest warrant is to be executed. For example, pursuant to Article $91(2)(\mathrm{c})$, the court is obliged to accompany an arrest warrant with sufficient information and evidence to meet the requirements for the surrender process in the requested state. In the practice of the ICTR, domestic evidentiary requirements are more demanding than the prima facie standard applied by the

40. ICC Statute, supra note 1 , at 43.

41. Id.

42. The ICTY and ICTR arrest procedures are based on the questionable assumption that a certain level of proof that an individual has committed crimes within the Tribunals' jurisdiction is sufficient grounds for arrest. The apparent irrelevance of this condition derives from the ICTR's Rule 65, according to which an accused must prove exceptional circumstances to obtain a judicial order for provisional release. From the perspective of human rights, the reverse situation is far more appropriate. The Prosecutor should offer proof to justify the issuance of an arrest warrant. The ICTY Judges have amended Rule 65 by removing the exceptional circumstances requirement. Therefore, the matter is highly controversial in ICTR case law. See Prosecutor v. Nahimana, Decision on the Defence's Motion for Release or Alternatively Provisional Release of Ferdinand Nahimana, Case No. IT-99-52-T, T. Ch. I, 5 Sept. 2002.

43. Fourmy, supra note 34 , at 1219 . In ICTY jurisprudence a prima facie case is "a credible case which would (if not contradicted by the defense) be a sufficient basis to convict him of that charge." See, Prosecutor v. Milosevic, in ANNOTATED LEADING CASES OF INTERNATIONAL CRIMINAL TRIBUNALS: THE INTERNATIONAL CRIMINAL TRIBUNAL FOR THE FORMER YUGOSLAVIA 1993-1998 35, 36, para. 4 (Andre Klip \& Goran Sluiter eds., 1999); Decision on the Review of the Indictment, Prosecutor $v$ Kordic, Case No. IT-95-14-I, Judge Gabrielle Kirk McDonald, 10 Nov. 1995, at 3 (adopting the Report of the International Law Commission, U.N. Doc. A/49/10 (1994), at 95). Arguably, the "reasonable grounds" test seems to lie below this standard. 
Tribunal. $^{44}$ Therefore, with a view to swift execution of the arrest warrant, it is recommended that both the Prosecutor and Pre-Trial Chamber anticipate these domestic requirements.

Article 58(1)(b) lists three alternative purposes that the arrest should serve. One such purpose is "to ensure the person's appearance at trial. ${ }^{45}$ However, because the court lacks an effective enforcement mechanism, Article 58(1)(b) presents a fairly low threshold for applicability.

\section{B. The Issuance and the Transmission of the Request for Arrest and Surrender}

Article 58(5) of the ICC Statute connects the issuance of the arrest warrant with the issuance of a request for arrest and surrender to a state. According to this provision, the court may issue such a request under Part 9, only after an arrest warrant has been issued under Article 58. ${ }^{46}$ Part 9 contains the regulations and conditions pertaining to the issuance and transmission of requests for an arrest and surrender, with one important exception: the provisions under Part 9 are procedural.

The procedural requirements are set out in Articles 87 and 91 of the Statute. Sections 1 and 2 of Article 87 contain regulations on the channel of communications and the choice of languages regarding requests for assistance. According to Article 87(1)(a), requests for assistance shall be transmitted through the diplomatic channel or any other appropriate channel designated by each state party. The language of the request shall be in the official language of the requested state or one of the court's working languages, as the state party chooses. ${ }^{47}$ These regulations are similar to those in

44. The transfer of Eliziphan Ntakirutimana from the United States to the ICTR was refused by a U.S. District court holding that the Fourth Amendment's probable cause standard was not met. In re Elizaphan Ntakirutimana, 988 F.Supp. 1038 (S.D. Tex. 1997). The matter was remedied on appeal, after the ICTR had supplemented the available evidence. Ntakirutimana v. Reno, 184 F.3d 419, 428, 430 (5th Cir. 1999).

45. In domestic criminal jurisdictions, this ground is known as the "risk of flight" and is generally applied to suspects of foreign nationality or to suspects without a permanent residence.

46. The power to issue requests for assistance is attributed to the court as a whole, including all of its organs. Part 9 does not specify the organ empowered to request the arrest and surrender. It appears self-evident, however, that the Pre-Trial Chamber remains the competent organ in this respect.

47. Some thirty states have lodged a declaration under Article 87(2) of the Statute concerning the choice of languages. Concerning those states which have not done so, they 
the Inter-State Cooperation Model. ${ }^{48}$ It is clearly a concession to states in favour of a more horizontally oriented cooperation model. ${ }^{49}$ One may wonder whether strict adherence to diplomatic channels and choice of national languages may not hamper the effective provision of legal assistance..$^{50}$ More flexible rules on this matter seem more appropriate in light of the nature of the relationship between states parties and the court.

Article 91 of the Statute contains the procedural requirements pertaining to requests for arrest and surrender. The request for arrest and surrender must contain a description that is sufficient to identify the person sought, a copy of the arrest warrant, and in case the person sought has already been convicted, a copy of the judgement of conviction. More controversial is Article 91(1)(c), which requires that the request be supported by documents, statements or information as may be necessary to meet the requirements for the surrender process in the requested state. This provision concerns the required domestic evidentiary standard for arrest and surrender. The issue was a matter of great concern for common law states. ${ }^{51}$ States found it unacceptable to arrest and surrender individuals without the same level of proof required under domestic law. ${ }^{52}$ In response to the states' objections, Article 91 allowed the same application of evidentiary requirements as those applicable to requests for extradition. This may result in different evidentiary standards in the practice of arrest and surrender. Whereas certain states may not require further evidence from the court and will be satisfied by the

will receive requests for assistance in one of the working languages of the court, English or French. See ICTY AND ICTR RULES, supra note 3, at 219.

48. See, e.g., European Convention, supra note 5, at 7, 9.

49. See Claus Kress \& Kimberly Prost, Article 87, in Commentary ON THE Rome STATUTE OF THE INTERNATIONAL CRIMINAL COURT: OBSERVERS' NOTES ARTICLE BY ARTICLE, supra note 3, at 1055, 1057-58.

50. In urgent situations, there may not be enough time to go through diplomatic channels to translate a request into an official national language. The Statute and Rules do not provide flexible rules regarding channels of communications and choice of languages. As a result, even in urgent situations, party states may insist on a channel of communication and choose a language that is tantamount to a ground for refusal. See ICC Statute, supra note 1 , at 69.

51. For more detail, see Claus Kress \& Kimberly Prost, Article 91, in CoMmEnTARY

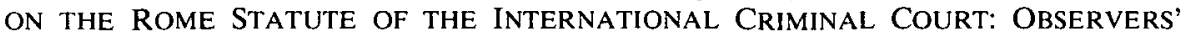
NOTES, ARTICLE BY ARTICLE, supra note 3, at 1091.

52. Id. 
"evidentiary test" applied by the court that issued the arrest warrant, other states may be more demanding.

Article 98 of the ICC Statute imposes a more substantive condition on the issuance of arrest and surrender requests by the court. According to this provision, the court may not proceed with a request for surrender that will force the requested state to act inconsistently with its obligations in the field of state and diplomatic immunity, and its obligations under treaties that require the consent of a sending state for surrender (so-called status of forces agreements). Although this provision acts as a condition to the issuance of a request for assistance, it can also be inserted in the Statute as a material ground for refusing the provision of assistance, as was done with other competing obligations under international law. ${ }^{53}$ This provision will be examined further as a material ground for refusal in Part V.C.2 below.

\section{Proceedings at the National LeVel}

The implementation of a request for arrest and surrender is governed by both Article 59 and the relevant provisions of Part 9 of the Statute. Whereas Part 9 contains essentially obligations that give effect to the request, Article 59 contains the method of implementation. The interplay between Part 9, in particular Articles 89 and 58, is complicated. According to Article 89(1), national procedures govern the treatment of requests for arrest and surrender. This suggests that a state is free to choose the means and method of implementation, as long as surrender is obtained. This freedom, however, is restricted by Article 59 of the Statute, which contains a number of concrete obligations regarding the implementation of a request for arrest. In addition to Article 59 , state implementing a request for arrest and surrender must comply with the provisions of Article 55. Article 55 grants a number of rights to individuals during an investigation; the most

53. See ICC Statute, supra note 1, at 57,67-69. With respect to immunity obligations, however, a number of delegations found it unacceptable that the court could place a state in a potential position of conflict with existing obligations. See Kimberly Prost \& Angelika Schlunck, Article 98, in COMMENTARY ON THE ROME STATUTE OF THE INTERNATIONAL CRIMINAl COURT: OBSERVERS' NOTES, ARTICLE BY ARTICLE, supra note 3, at 1131 , 1132 . 
important right being the right to freedom from arbitrary arrest or detention. $^{54}$

\section{A. Organisation of the Arrest Proceedings}

The obligations of Article 59 protect the rights of the arrested person at the national level. The provision underlines the duty to comply swiftly with requests for arrest, a matter that is dealt with in Part 9. The desire to ensure protection of individual rights at the national level is recommended, even if it seems to contradict the division of tasks between the court and national jurisdictions regarding arrest and surrender. The Statutes and Rules of the ICTY and ICTR do not contain a similar provision. ${ }^{55}$ This protection is included because the Tribunal violated the arrestees' rights when it initially requested the arrest. ${ }^{56}$

Article 59 contains a number of important safeguards for the arrested person. First, the custodial state is obligated to bring the arrested person promptly before its judicial authorities. ${ }^{57}$ The judicial authorities must then determine whether the arrest warrant applies to the arrested person, whether the person was arrested according to proper procedure, and whether the person's rights have been respected. It is unclear what these obligations entail exactly. In particular, it is unclear what is meant by the

54. ICC Statute, supra note 1, at 52. Furthermore, Article 55(2) applies to the Prosecutor or national authorities' questioning of an individual, pursuant to a request made under Part 9. It also applies to hearings connected with the Article 59 arrest proceedings. As a result, the arrested person is entitled to remain silent, to have legal assistance of his choosing and to be questioned in the presence of counsel. In particular, this last right is not obvious in several civil law jurisdictions with respect to extradition related interrogations. See, e.g. Prosecutor v. Mucic, supra note 38, at 227.

55. "The provisions in the RPE of the Tribunals on arrest and detention of suspects and accused persons for the purpose of transferring them to their seats mainly concentrate on the duties of states vis-à-vis the Tribunals. To a certain extent these rules neglect the rights of the individual persons concerned ...." Bert Swart, Arrest Proceedings in the Custodial State, in 2 THE ROME STATUTE OF THE INTERNATIONAL CRIMINAL COURT: A COMMENTARY 1247, 1251 (Antonio Cassese et al. eds., 2002).

56. See Barayagwiza v. Prosecutor, in ANNOTATEd LEAdING CASES OF INTERNATIONAL CRIMINAL TRIBUNALS: THE INTERNATIONAL CRIMINAL TRIBUNAL FOR RWANDA 1994-1999, ALC-II-129 (Andre Klip \& Goran Sluiter eds., 2001); Prosecutor v. Barayagwiza, in ANNOTATED LEADING CASES OF INTERNATIONAL CRiminal Tribunals: THE INTERnational Criminal Tribunal for RWANDa 1994-1999, ALC-II-129 (Andre Klip \& Goran Sluiter eds., 2001).

57. See ICC Statute, supra note 1, at 45; see also International Covenant on Civil and Political Rights, at 20, U.N. Doc. A/RES/2200(XXI) (1967) [hereinafter ICCPR]. 
"person's rights." 58 Are these rights under domestic law, under the Statute, or under international human rights law? Commentators have suggested that the drafters essentially had international human rights law in mind, especially the arrested person's right to be informed about the charges and the grounds for detention, as protected by Article $9(2)$ of the ICCPR. ${ }^{99}$ However, the ordinary meaning of "person's rights" is much broader. Given the mandatory language used in Article 59(2), "shall determine," it is likely a national judge may review the arrest in light of a considerable number of individual rights.

Second, Article 59(3) protects the arrested person's right to apply for an interim release to the competent authority in the custodial state that implements the protection offered by Article 9(4) of the ICCPR. The fact that national authorities can eventually order the interim release of an arrested person, without the permission of the court, deviates greatly from the ICTY and ICTR arrest proceedings and would fit better into a "horizontal" cooperation model. ${ }^{60}$ Nevertheless, the national judicial authorities must give full consideration to the recommendations made by the ICC Pre-Trial Chamber on the arrested person's interim release. $^{61}$ It comes as no surprise that strict conditions govern the interim release applications, because they were driven by the fear that detention might too easily be suspended. Thus, Article 59(4) mentions "exceptional circumstances",62 and "safeguards ... to ensure ... surrender." Article 59(4) also explicitly provides that national authorities may not consider whether the arrest warrant was properly issued under Article 58. This limitation is unique because no other provision in the Statute or Rules prevents a state from addressing the legality of a request for assistance. ${ }^{63}$ Strictly speaking, one should distinguish the arrest

58. ICC Statute, supra note 1 , at 45.

59. See Angelika Schlunck, Article 59, in COMmEnTARY ON THE Rome STATUTE OF the International Criminal Court: ObSERvers' Notes, ARTIClE by ARTiCle, supra note 3 , at 765,768 . In light of the rights set out in the Statute, a national review of the arrest warrant, especially the right not to be subjected to arbitrary arrest or detention, exceeds the competence of the national judge. Swart, supra note 7, at 1253-54.

60. Swart, supra note 7 , at 1254.

61. See ICC Statute, supra note 1, at 74; see also ICTY AND ICTR RULES, supra note 3 , at 452 .

62. For an example of an arrested person who is on death row, see Schlunck, supra note 59 , at 769 .

63. See infra Part IV.B. 
warrant from the request for arrest and surrender. The former is not susceptible to review at the national level, whereas the latter is subject to the requirements of Article $91(2)(\mathrm{c})$, and must be supported by sufficient evidence. An interim release on account of insufficient evidence is, therefore, not based on the ultra vires character of the warrant, but on an alleged court violation of Article 91(2)(c).

Once the requested person is ordered to be surrendered, he shall be delivered to the court as soon as possible. After surrender, an initial appearance before the Pre-Trial Chamber follows, and the Chamber ensures that the various rights concerning arrest and detention are observed in accordance with Article 60 of the ICC Statute. $^{64}$

\section{B. Protection of the rights of the arrested person}

The Statute purports to protect the arrested person's rights both at the domestic level and within the jurisdiction of the court. However, the extent to which the arrested person will in fact benefit from this protection is a different matter. It depends on the enforcement of the obligations set out in Article 59 and the availability of legal remedies for any violation of individual rights.

Under Article 59, a state has the duty to adequately supervise the individual rights of the arrested person. Additionally, because these obligations are imposed by Statute, the court should have a role in their enforcement as well. The protection of individual rights, however, is a different nature than the cooperation obligations under Part 9 of the Statute. Consequently, the obligations under Article 59 appear exempt from the enforcement mechanism of Article 87(7), which allows the court to refer noncompliant states to the Assembly of States Parties. It is also exempt from any action taken by the Assembly of States Parties pursuant to Article 112(2)(f).

Another issue concerning the practical application of Article 59 is the availability of legal remedies. As previously discussed, Article 59(2) requires national judicial authorities to determine whether the arrested person's rights have been respected. However, the provision is silent as to what happens upon a

64. Article 55 is not the only provision that sets out applicable rights. Under Article 21(3), the entire human rights corpus could bind the court in its activities. For more detail, see SLUITER, supra note 17 , at 46. 
determination that a person's rights have in fact been violated. Do the national authorities grant the remedies they deem appropriate? Although this may follow from the role attributed to the national authorities, as envisaged by Article 59(2), the competent national court cannot grant remedies that may impede the execution of the request without first consulting with the court. $^{65}$ As such, immediate release would be in violation of a state's obligations under the Statute. ${ }^{66}$

The Statute is also silent as to whether appellate proceedings at the national level are permissible. However, given the references to domestic law in both Article 59(1) and Article 89(1) of the Statute, appellate proceedings are not likely to be excluded. ${ }^{67}$ Moreover, depending on the custodial state, the arrested person may request the international human rights courts or supervisory mechanisms to review the arrest and surrender in light of the state's obligations under certain human rights treaties. ${ }^{68}$

A court may not easily grant the release of a person accused of the most serious international crimes. ${ }^{69}$ However, with respect to serious human rights violations in the course of or following the arrest, the effective legal remedies provision may be indispensable

65. See ICC Statute, supra note 1, at 75. Accord infra Part V.B (analyzing the duty to consult).

66. The abduction of the person accompanied by serious mistreatment is an exception for egregious violations of human rights in the apprehension of the requested person. In this situation, the competent national judge may rightfully assume that his duties under Article 59(2) do not tolerate any further detention.

67. A majority of party states will not, in light of the remedies available under the ICC Statute, provide appellate procedures with respect to surrender to an international criminal tribunal. E.g., Article 27(4) of the Dutch "ICC Cooperation Act" (Official citation: Rijkswet van 20 juni 2002 tot uitvoering van het Statuut van het Internationaal Strafhof met betrekking tot de samenwerking met en bijstand aan het Internationaal Strafhof en de tenuitvoerlegging van zijn vonnissen (Uitvoeringswet Internationaal Strafhof) (Staatsblad 2002, 314)) (translated into English by author).

68. The only example is the complaint by Naletilic, to the European Convention on Human Rights, claiming that his surrender to the ICTY by Croatia would violate the latter's obligations under the Human Rights Convention. In particular, plaintiff contended that the ICTY would not offer him a fair trial. The plaintiff placed the emphasis on the actual surrender rather than the method of arrest and ensuing detention. Naletilic v. Croatia, EUR. CT. OF H.R. App. No. $51891 / 99$ (2000) available at http://www.echr.coe.int/Eng/Judgments.htm (last visited Sept. 21, 2003).

69. See Susan Lamb, The Power of Arrest of the International Criminal Tribunal for the Forner Yugoslavia, 70 BRIT. Y.B. INT'L L. 165, 240 (2000). 
in preserving the integrity of the subsequent international criminal proceedings.

\section{The Duty to SURRENDER THE REQUeSTED PERSON}

The central issue, both for the custodial state and for the arrested person, remains the precise content of the duty to surrender. As previously stated, the ICC surrender regime imposes heavier obligations on states than on traditional international extradition law. ${ }^{71}$ The section below discusses in detail the scope of these obligations in light of their effectiveness and legal protection.

\section{A. Implementing the Duty to Surrender}

Pursuant to Article 88, a state party has a clear duty to ensure that its national laws provide guidelines for handling requests for arrest and surrender, and other forms of cooperation. This duty arises even before a state party ever receives a request. ${ }^{72}$ When establishing the ICTY and ICTR, the Security Council was concerned that the absence of national laws and procedures would impair assistance and, therefore, impose a duty for the states to enact, if necessary, laws allowing the provision of legal assistance. ${ }^{73}$

The insertion of Article 88 in the ICC Statute is particularly important because of certain references to domestic law and procedures throughout the Statute. For example, pursuant to Article $89(1)$, state parties shall comply with requests for arrest and surrender in accordance with the provisions of Part 9 and the

70. This appears to be the prevailing view in cases before both the ICTR and ICTY. See Prosecutor v. Barayagwiza, supra note 55, at 129; see also Prosecutor v. Nikolic, Case No. IT-94-2-PT, I111, 114 (2002) at http://www.un.org/icty/nikolic/trialc/decisione/10131553.htm (last visited Sept. 21, 2003). Accord infra Part VI.B.

71. See discussion infra Part II.C.1.

72. Unfortunately, the obligation only pertains to Part 9 and does not extend to other Parts of the Statute. The obligation set out in Part 10 Article 109 of the ICC Statute can enforce an order to freeze assets.

73. Compare S.C. Res. 955, U.N. SCOR, 49th Sess., 3453d mtg. Il2, U.N. Doc. S/RES/955 (1994) and S.C. Res. 978, U.N. SCOR, 50th Sess., 3504th mtg., U.N. Doc. S/RES/978 (1995) with S.C. Res. 827, U.N. SCOR, 48th Sess., 326th mtg. II4, U.N. Doc. S/RES/827 (1993) and S.C. Res. 1207, U.N. SCOR, 53d Sess., 3944th mtg. I11-2, U.N. Doc. S/RES/1207 (1998) (concerning the ICTR and ICTY, respectively). In the Blaškic subpoena decision, the ICTY Trial Chamber emphasized that states are required to create internal legislation that would enable them to fulfill their duty to comply with orders of the Tribunal. Prosecutor v. Blaškic, Case No. IT-95-14-T I84 (1997) at http://www.un.org/ icty/blaskic/trialc1/judgement/index.htm (last visited Sept. 21, 2003). 
procedure under their national law. Reading Article 89(1) in conjunction with Article 88 , it is clear that a state may not use the absence of a domestic legal basis as an excuse for their failure to comply with a surrender request. ${ }^{74}$ The scope of Article 88 does not, however, go so far as to exclude domestic law as a general ground for refusal, because the provision only obliges states to have procedures available, and does not require they be effective. ${ }^{75}$

States are expected to implement Article 88 in good faith, like any other obligation under the Statute. They should, however, be given enough time to make the legislative changes at the national level. Compared to the statutes of the ad hoc tribunals, the ICC Statute offers far more guidance as to how the provision of assistance is organised and, as a result, is much more informative about the legislative steps to be taken. ${ }^{76}$

\section{B. Obstacles in the Implementation: The Duty to Consult}

Before addressing the substantive content of the duty to cooperate, especially the question of applicable grounds for refusal, the procedural aspects of the duty to cooperate must first be examined. For example, what are the obligations of a requested state when it is confronted with a request for assistance that it has determined it cannot implement? Adequate provisions in this respect allow for misunderstandings to be eliminated and alternative modes of cooperation considered. ${ }^{77}$

The procedures that a state must follow when it receives a request for assistance that it has trouble complying with are more specific under the ICC than under the ICTY and ICTR Statutes. States are under an explicit obligation to consult with the court when problems arise which may impede the execution of the request. The duty to consult, aiming at resolving "obstacles" in the

74. See Claus Kress \& Kimberly Prost, Article 89, in COMMENTARY ON THE ROME STATUTE OF THE INTERNATIONAL CRIMINAL COURT: OBSERVERS' NOTES, ARTICLE BY ARTICLE, supra note 3, at 1072,1074-75.

75. For more detail, see SLUITER, supra note 17, at 194-97.

76. For an analysis of domestic laws implementing the ICTR and ICTY cooperation regimes, see Göran Sluiter, Obtaining Evidence for the International Criminal Tribunal for the Former Yugoslavia: An Overview and Assessment of Domestic Implementing Legislation, 45 NETH. INT'L L. REV. 87, 87-113 (1998).

77. Bert Swart \& Göran Sluiter, The International Criminal Court and International Criminal Cooperation, in HERMAN A. M. VON HEBEL ET AL., REFLECTIONS ON THE INTERnATIONAL CRIMINAL COURT: ESSAYS IN HONOUR OF ADRIAAN BOS 91, 104 (Johan G. Lammers \& Jolien Schukking eds., 1999). 
provision of legal assistance, is prominent throughout Part 9 of the ICC Statute. ${ }^{78}$ It is used several times with respect to specific obligations to cooperate. It is also referred to more generally in Article 97, which imposes upon states a duty to consult with the Court with respect to every request for assistance issued under Part 9 of the ICC Statute. If the state is unable to resolve the matter after consulting with the court, Articles 87(7) and 119 provide that it is the duty of the court to determine how the state should cooperate. This grant of power is a feature unique to the vertical cooperation regime, as was already established above.

The insertion of the duty to consult in the ICC Statute suggests that states are not a priori prevented from submitting grounds for refusal to the court for evaluation, even if these grounds are not set out in the Statute. The language of Article 97 of the Statute supports this position. It contains an illustrative list of obstacles that states may submit to the court. Thus the door is opened to the submission of a variety of obstacles to the execution of a request. ${ }^{80}$

However, room to review the requests for assistance does not exist when states are explicitly prohibited from reviewing or refusing to comply with the requests for assistance. For example, Article 59(4) of the ICC Statute provides that it is not open to the competent authority of the state requested to arrest a person to consider whether the arrest warrant was properly issued in accordance with Article 58, paragraph 1 (a) and (b) of the ICC Statute. A contrario, in other situations, the requested state may submit obstacles that impede execution of the request. This includes the objecting to the alleged ultra vires character of the request. However, once these "obstacles" are not accepted by the requesting court or Tribunal, the requested state is under an obligation to give effect to the request.

78. Swart \& Sluiter, supra note 77, at 103.

79. See discussion infra Part II.C.3.

80. Article 97 has already been interpreted by the Netherlands as implying a certain right to review requests for assistance in light of grounds other than those set out in the Statute. This interpretation was, however, immediately followed by the determination that in every cooperation dispute the court is the ultimate arbiter. See Dutch Cooperation Act, $T K$, vergaderjaar 2000-2001, 28098 (R1704), no. 3, 7-9 (explanatory memorandum) (translated into English by author). 


\section{Grounds in the Statute to Refuse or Postpone Surrender}

As a result of protracted and sometimes painful negotiations between supporters and opponents of the far-reaching obligations of the states to the court, specific grounds for refusal and postponement of legal assistance were inserted into the ICC Statute. $^{81} \quad$ Because the insertion of grounds for refusal and postponement of assistance resulted from long and complex negotiations, one may argue that, other than those provided in the statute, no other grounds may be advanced by states to refuse or postpone assistance. In other words, the ICC Statute is, as far as the cooperation regime is concerned, a "self-contained regime," which should provide all the answers pertaining to the content of the duty to cooperate. ${ }^{82}$ Kress and Prost also believe that the very careful determination of the scope of obligations to co-operate during the Rome negotiations certainly points in this direction. However, this view does not conform to a systematic interpretation of the Statute. The duty to consult, as set out in Article 97 of the ICC Statute and as already examined in the paragraph above, is not necessarily confined to problems of implanting one of the grounds for refusal as set out in the Statute. The drafters of the Statute, conducting the detailed and protracted negotiations, could not have reasonably foreseen all the problems that may occur in the practical application of the ICC legal assistance regime.

\section{Competing Requests}

The drafters of the Statute were aware that certain requests for assistance issued by the court might conflict with a state's other international obligations. ${ }^{84}$ In contrast to the ad hoc tribunals, the ICC does not take priority over other international obligations,

81. For an account of the drafting history in this respect, see Mochochoko, supra note 8 , at $310-14$.

82. The concept of self-contained regimes came from the ICJ decision of United States Diplomatic and Consular Staff in Tehran (U.S. v. Iran), 1980, I.C.J. 60, 3 (May 24). The court held that the exclusive remedy for unlawful activities by diplomats is found in International Law regarding diplomatic immunities, also considered a "self-contained regime." Id. For more detail, see Bruno Simma, Self-Contained Regimes, 1985 NETH. Y.B. INT'L L. 111-36.

83. See Claus Kress \& Kimberly Prost, Article 87, in COMMENTARY ON THE ROME STATUTE OF THE INTERNATIONAL CRIMINAL COURT: OBSERVERS' NOTES, ARTICLE BY ARTICLE, supra note 3, at 1055, 1066.

84. See Mochochoko, supra note 8, at 314. 
such as that provided for in Article 103 of the UN Charter. As a new international organisation, the ICC must be aware of and respect the existing obligations of states under international law. If this had not been the case, states would simply not have ratified the Statute.

When obligations conflict, the guiding principle is that priority should be given to the obligations under the Statute. Furthermore, if the competing obligation is owed to another state party, the obligation towards the court shall prevail. ${ }^{85}$

Article 90 of the Statute addresses the conflict between the obligation to surrender and the obligation to extradite under a treaty. It is an elaborate provision, proposing various solutions to competing and irreconcilable requests for surrender. First, states must notify the court of a competing request. If the competing request comes from another state party, the request from the court enjoys priority when the case has been declared admissible (see Article 90 (2) of the ICC Statute). When the competing request comes from a nonparty state, the requested state shall give priority to the request from the court if the requested state has no obligation under international law to comply with the competing request (Article 90 (4) of the ICC Statute). However, if there is an obligation towards the nonparty state, Article 90 ultimately leaves it to the requested state to choose between the requests. ${ }^{86}$

One may wonder the extent to which competing extradition obligations may be used as a tool to keep wanted war criminals out of the hands of the court. Almost all extradition treaties contain provisions on concurring extradition requests. These provisions enable the requested state to make a choice between the various requests. ${ }^{87}$ Thus, states may give priority to the ICC to surrender requests without much difficulty. Whether they are prepared to surrender, however, is a different matter. One must applaud the host state's position. If a requesting state categorically denies the

85. Under the ICC Statute, a state party may be absolved from complying with a request for extradition coming from another state party.

86. With respect to competing requests for surrender, this applies both to competing requests based on crimes within the court's jurisdiction and to competing requests based on other crimes. However, in making the decision whether or not to give priority to the request of the court, the requested state is obliged to take into account all relevant factors, including the respective dates of the requests, the interests of the requesting state and the possibility of subsequent surrender to the court. See ICC Statute, supra note 1, at 68.

87. Swart, supra note 7, at 1697; see, e.g., European Convention, supra note 5, at 8. 
jurisdiction of the court, then the Netherlands will give priority to the request for surrender.

\section{Article 98: Immunities and Exclusive Jurisdiction}

Article 98 of the ICC Statute, which was already alluded to in Part III.B, provides that the court may not proceed with a request for surrender or assistance that would require the requested state to act inconsistently with its obligations under international law. The state must respect a third state's diplomatic immunity. Article 98 arose out of the concern that a state should not be obliged to act in breach of pre-existing obligations under international law. Thus, it bears similarities to Article 90. Contrary to those provisions, however, Article 98 limits the court from issuing a request in the first place, because it may place a state in an unacceptable position of conflict. ${ }^{89}$

Article 98 of the ICC Statute, as a ground to refuse assistance, recognises protections flowing from international obligations relating to diplomatic or state immunity. Additionally, it recognises those obligations arising from an agreement, such as Status of Forces agreements. These latter agreements provide exclusive jurisdiction over troops stationed in another state. ${ }^{90}$ In situations when the court requests a state to surrender a diplomatically immune prisoner, or a foreign soldier enjoying protection from a Status of Forces agreement, it must seek waiver of immunity. ${ }^{91}$ The Article adopted this obligation to ensure that the person is subject to the control of another state, and that state does not have to choose between the sending state and the court.

Article 98 of the ICC Statute envisages that the court should first seek to a obtain waiver of immunity from the third state before issuing a request violating a state's immunity obligations. Contrary to Article 90 of the ICC Statute, Article 98 does not contain a provision that mandates a third state's obligation to grant waiver of the immunity. This conflict would then be a matter between two states parties and the court. For the Article's framers

88. See Dutch Cooperation Act, supra note 80, at 29.

89. Given its similarity to Article 90 , it Article 98 is best examined in this section of the Article.

90. See, e.g., North Atlantic Treaty, supra note 6, at 78 (regulation of concurrent jurisdiction conflicts).

91. Without such a waiver or consent, the requested state may refuse to execute a request for arrest or surrender. 
to insert this type of provision would have appeared obvious. The question of whether the third state has a duty to waive the immunity, or to give the consent, is left to the duties of states parties under Part 9.

An important element of Article 98 is that it leaves the court to determine whether implementation of a request requires the state to act inconsistently with its obligations in the field of state and diplomatic immunities. In making that determination, the court will not only subject itself to its own Statute, in particular Article 27, but also to develop international law related to diplomatic and state immunities. States nonparties are not bound by Article 27 of the ICC Statute, but this provision reflects customary international law. Heads of state do not enjoy state immunity for the crimes within the court's jurisdiction. In the ICTY decision on preliminary motions by Miloševic, the Trial Chamber explicitly confirmed that customary international law ensures that no person, in whatever official capacity, enjoys immunity before an international tribunal when he or she is accused of the most serious international crimes. ${ }^{92}$ Also, the recent judgement by the ICJ in the Congo-Belgium case acknowledges, in my view, that current international law for state and diplomatic immunities are not applicable to arrests and surrenders at the request of the $\mathrm{ICC}^{93}$

The use of Article 98 as a possible ground for refusal has recently received a lot of attention. In a campaign to keep its nationals out of the hands of the court, the United States intends to conclude a number of treaties with ICC states parties that require consent from the requested person's national states before that person may be surrendered to the ICC. ${ }^{94}$ By concluding such

92. Prosecutor v. Slobodan Miloševic, Decision on Preliminary Motions, Case No. IT99-37-PT, T. Ch. III, 8 Nov. 2001, paras. 26-34.

93. Case Concerning the Arrest Warrant of 11 April 2000 (Democratic Republic of Congo v. Belgium), Feb. 14, 2002, para. 61, (an acting Minister of Foreign Affairs may be subjected to criminal proceedings before certain international criminal courts, including the ICC regardless of whether the individual is a high state official of party states or nonparty states), at http://www.icj-cij.org/icjwww/idocket/iCOBE/iCOBEframe.htm (last visited Sept. 21, 2003).

94. The most relevant provisions of the Article 98(2) agreements state:

For purposes of this agreement, "persons" are current or former Government officials, employees (including contractors), or military personnel or nationals of one Party.

Persons of one Party present in the territory of the other shall not, absent the 
agreements, the United States hopes to trigger the application of Article 98 (2), and prevent the court from proceeding with a request for surrender without U.S. permission. It is unclear, however, whether the agreements will produce the desired result and the court considers them to bar the issuance of the request for surrender. One argument the court is considering is that only the existing obligations of states parties fall within the scope of application of Article 98 (2). ${ }^{95}$

\section{Ne-bis-in-idem}

Ne-bis-in-idem (double jeopardy) is not truly a ground to refuse surrender to the court. Whether or not the arrested person has already been diligently tried by another court for conduct within the jurisdiction of the ICC, which is the basis for the arrest warrant and surrender request, is a matter best left to the court pursuant to Article 20 of the Statute. Thus, when the requested person submits a ne-bis-in-idem claim to the competent domestic court, the requested state, pursuant to Article 89(2) of the Statute, shall immediately consult with the court. The court and state shall determine the admissibility of the case. Pending the admissibility ruling, the requested state may postpone the execution of the surrender request. ${ }^{96}$

\section{Postponing the Request for Surrender}

The ICC Statute explicitly allows the requested state to postpone the provision of legal assistance under certain conditions. This is not the same as a ground for refusing assistance. The latter,

expressed consent of the first Party, be surrendered or transferred by any means to the International Criminal court for any purpose, or be surrendered or transferred by any means to any other entity or third country, or expelled to a third country, for the purpose of surrender to or transfer to the International Criminal court.

95. See Prost \& Schlunck, supra note 53, at 1132. Article 98(2) is similar to Article $90(6)$ which provides that a party state's duty to comply with other obligations can only be used as a ground to refuse its surrender of an individual if the obligation is under an existing extradition treaty. ICC Statute, supra note 1, at 75 . Furthermore, treaties that have the sole purpose of keeping individuals out of the reach of the court amount to a violation of the overall duty to cooperate with the court in good faith and therefore will not to be taken into account. Also, Article 98(2) explicitly refers to a party state's obligations towards a "sending state". As a result, only obligations to send certain individuals, such as military troops and diplomats, to another state are envisaged., Treaties including every U.S. national, however, exceed the scope of Article 98(2).

96. See discussion infra Part V.C.4. 
if accepted by the court, is final. The former, however, may temporarily suspend the duty to provide assistance. It regains its force when the "conditions of postponement" are no longer applicable. The difference between refusal and postponement may only be marginal in practice, particularly if it concerns a request that begs for swift execution. ${ }^{97}$ The main ground for refusal addresses the right to postpone legal services.

The grounds for postponement have one positive effect for effective legal assistance. To the extent it was not already apparent on the basis of other provisions, it underlines that the "general rule" is immediate execution of requests, and postponement is the exception.

Article 95 of the ICC Statute allows a state to postpone the execution of a request pending the determination by the court of the case's admissibility pursuant to Article 18 or 19 of the Statute. The provision puts the principle of complementarily into effect. According to this principle, prosecution should take place at the national level and the court may only exercise jurisdiction if a state is unwilling or unable to prosecute a case. According to Article 95, until it is certain that the court may actually exercise jurisdiction, there is no need to assist the court.

With respect to the duty to surrender persons in addition to Article 95, there are two special provision in Articles 89 and 90. Article $89(2)$ dealing with requests for arrest and surrender, provides that "[i]f an admissibility ruling is pending, the requested state may postpone the execution of the request for surrender of the person until the court makes a determination on admissibility." Furthermore, Article 90(2), which deals with competing surrender requests, provides that priority must be given to a request from the court, only after the case has been declared admissible. Prior to that declaration, a state can choose to give effect to the competing request from another state.

Article 94 of the Statute allows a state to postpone the execution of any request for assistance if immediate execution would interfere with an ongoing investigation or prosecution. This

97. The "postponement solution" was the result of a compromise between delegations that favored a material ground for refusal and those that did not. See Kimberly Prost \& Angelika Schlunck, Article 95, in COMMENTARY ON THE ROME STATUTE of THE INTERNATIONAL CRIMINAl COURT: OBSERVERS' NOTES, ARTICLE by ARTICLE, supra note 3, at 1123; see also Swart \& Sluiter, supra note 77, at 107.

98. See ICC Statute, supra note 1 , at 73 (referring to immediate execution). 
provision was initially envisaged as a ground for refusal, but now it is a ground for postponement. ${ }^{99}$ The provision recognises the interests of states to protect their domestic investigations and prosecutions. However, if domestic interests in investigations and prosecutions, concern the commission of "ordinary crimes," they are of such a weight as to postpone the provision of legal assistance.

\section{Applicability of Other Grounds for Refusal}

Under Article 97, state parties to the ICC cannot be prevented from submitting to the court by obstacles other than those explicitly set out in the Statute when requesting for arrest and surrender. Whether they will be recognised by the court on a justified ground is a different matter. The guiding principle should be the one enunciated by the Appeals Chamber in the Blaškic subpoena case. The requesting tribunal, or court, should be mindful of legitimate state concerns. ${ }^{100}$ These legitimate concerns, if they bar the provision of the assistance sought in every way, are to be balanced against the interests of the requesting tribunal, or court, to obtain the assistance. The Trial Chamber of the ICTY stated in the Blaškic subpoena case, referring to national security grounds for refusal:

In assessing the merits of an objection, the International Tribunal must consider two fundamental interests, the interest in upholding the national security interest of a state and the interest in gaining access to the evidence critical to the prosecution or defence in cases relating to serious violations of international humanitarian law. ${ }^{101}$

A number of factors are relevant to this balancing exercise, including whether assistance may be provided in other ways and

99. Kimberly Prost \& Angelika Schlunck, Article 94: Postponement of Execution of a Request in Respect of Ongoing Investigation or Prosecution, in COMMENTARY ON THE ROME STATUTE OF THE INTERNATIONAL CRIMINAL COURT: OBSERVERS' NOTES, ARTICLE BY ARTICLE, supra note 3, at 1119.

100. Prosecutor v. Tihomir Blaškic, Judgement on the Request of the Republic of Croatia for Review of the Decision of Trial Chamber II of 18 July 1997, in ANNOTATED LEADING CASES OF INTERNATIONAL CRIMINAL TRIBUNALS: THE INTERNATIONAL CRIMINAL TRIBUNALS FOR THE FORMER YUGOSLAVIA 1997-1999, ALC-I-245 (Andre Klip \& Goran Sluiter eds., 2001).

101. Prosecutor v. Tihomir Blaskic, Decision on the Objection of the Republic of Croatia to the Issuance of Subpoenae Duces Tecum, Case No. IT-95-14-T, T. Ch. II, 18 July 1997, para. 149, International Criminal Tribunal for the Former Yugoslavia. 
whether the state has generally cooperated in good faith with the requesting court. ${ }^{102}$

Concerning the invoked ground for refusal, the question as to its legitimacy and its weight, compared to the requesting court, is of the utmost importance. The interest of the court in obtaining the surrender of the requested person, whose presence is required to commence the trial, is a competing state interest of greater weight than probably any other refusal ground not in the Statute.

Nevertheless, a number of grounds for refusal will be examined below. The question of legitimacy and weight will be addressed, in the light of the particular nature of the ICC and the legal assistance relationship with these institutions. These grounds for refusal are traditionally used in the extradition framework.

\section{Nature of the Offence: Political and Military Offence Exception}

Grounds for refusal that based on the type of offence in extradition law include the "political, military or fiscal offence" exception. Given the nature of the crimes within the ICC's jurisdiction, the fiscal offence exception need not be examined. It is, however, worth exploring whether requested states considered the crimes within its jurisdiction as political and military offences and whether they have a legitimate interest in refusing assistance on that basis.

"Military offences" can be defined as acts "punishable only as a violation of military law or regulation, and which would not be punishable as a violation of a civil law or regulation if the military law or regulation did not apply." "The They are grounds for refusal in several extradition treaties. ${ }^{104}$ Although the offences within the court's jurisdiction may amount to a violation of domestic military codes, they are seldom only punishable as a violation of military law. Therefore, they can not be considered offences of an essential military character.

102. Cf. Prosecutor v. Tihomir Blaškic, supra note 100.

103. Harvard Draft Convention on Extradition, art. 6, 29 AM. J. INT'L L. (Supp.) 22 (1933); see Kenneth J. Harris \& Robert Kushen, Surrender of Fugitives to the War Crimes Tribunals for Yugoslavia and Rwanda: Squaring International Legal Obligations with the U.S. Constitution, 7 Crim. L.F., 561, 571 (1996).

104. See, e.g., European Convention, supra note 5, at 4.

105. See M. ChERIF BASSIOUNI, INTERNATIONAL EXTRADITION: UNITED STATES LAW AND PRACTICE 583 (3d ed. 1996) (arguing that the military offence exception cannot be applied when the charged acts constitute a crime under the ordinary laws of the requesting state and amount to war crimes); $c f$. Harris \& Kushen, supra note 103, at 571 
"Political offences" are of two types. The first category is "purely" political offences, which are exclusively directed against the state or political entity and are not accompanied by the commission of common crimes. The second category is "related" political offences, which are common crimes having a "political" element, being committed for a political purpose, out of a political motive, or the "political consequences" of the crime. ${ }^{16}$ It is standard in extradition treaties that the requested state may refuse extradition for political offences. ${ }^{107}$ Especially with "related" political offences, every crime within the jurisdiction of the court could potentially be considered a political offence. ${ }^{108}$ The whole concept of international crimes, based on the civitas maxima theory is that they should not remain unpunished, is that it is difficult to reconcile with the limitations on international cooperation on account of the political offence exception. This has resulted in the development of explicit exceptions to the political offence exception in certain international instruments relating to extradition in particular. ${ }^{109}$ As far as war crimes are concerned, however, the 1949 Geneva Conventions and the 1977 Additional Protocols do not exclude war crimes from the political offence realm. ${ }^{110}$ Consequently, the political offence exception could still be applied to war crimes. ${ }^{11}$ The ICTY Appeals Chamber, in the Tadic jurisdiction case, has, however, come to a different conclusion: "Crimes against the laws and customs of war cannot be considered political offences, as they do not harm a political

(arguing that the character of all offences could be considered either political or military if those terms are interpreted broadly).

106. See Dr. Christine VAN DEN Wijngaert, The Political Offence EXCEPTION TO EXTRADITION: THE DELICATE PROBLEM OF BALANCING THE RIGHTS OF THE INDIVIDUAL AND THE INTERNATIONAL PUBLIC ORDER 106, 108 (1980); see also Harris \& Kushen, supra note 103, at 571. "Related political crimes" is extremely wide and includes treason, espionage and conspiracy. See BASSIOUNI, supra note 105, at 515-18.

107. See, e.g., European Convention, supra note 5, at 3; see also BASSIOUNI, supra note 105, at 504 (examples of political offence exceptions to extradition treaties to which the United States is a party).

108. See Harris \& Kushen, supra note 103, at 571.

109. See, e.g., Convention on the Prevention and Punishment of the Crime of Genocide, U.N. GAOR Res. 260 A (III), Dec. 9, 1948, art. 7, 78 U.N.T.S. 278, 282 (stating that genocide "shall not be considered a political offence for the purposes of extradition"); Additional Protocol to the European Convention on Extradition, Oct. 15 1975, art. 1(a), Europ. T.S. No. 86 (providing that crimes against humanity, as discussed in the Genocide Convention, will not be considered political crimes for the purpose of extradition).

110. See VAN DEN WIJNGAERT, supra note 106, at 143.

111. See id. 
interest of a particular state, nor a political right of a particular citizen." In the Furundžija case, the Trial Chamber has reached the same conclusion with respect to torture. ${ }^{113}$ It can be concluded that the ICTY does not consider the crimes within its jurisdiction as political offences, or that the political offence exception may be invoked as a bar to extradition. It may thus also not be invoked as a ground to refuse surrender to the court.

Even if the political offence exception may be invoked to bar extradition for war crimes, it is not a legitimate obstacle to surrender war criminals to the ICC due to the underlying rationales. First, the exception is based on the court's desire to distance itself from the political conflicts in other states. ${ }^{114}$ Second, the exception is also linked to the idea that some morally reprehensible acts are justified by the circumstances surrounding the commission of the acts. ${ }^{115}$ Finally, the exception is justified by the greater risk that political offenders will receive an unfair trial. ${ }^{16}$ Because the ICC is an impartial and independent international criminal tribunal, the rationales listed above do not apply. Thus, the political offence exception should not bar the prosecution of war criminals by the ICC.

\section{Double Criminality Requirement}

Double criminality is a fundamental requirement of international extradition law. It requires that the act for which extradition is requested be a criminal offence in both the requesting and requested state. ${ }^{117}$ The requirement is found in

112. Prosecutor v. Tadic, Decision on the Defence Motion for Interlocutory Appeal on Jurisdiction, in ANNOTATED LEADING CASES OF INTERNATIONAL CRIMINAL TRIBUNALS: THE INTERNATIONAL CRIMINAL TRIBUNALS FOR THE FORMER YUGOSLAVIA 1997-1999, ALC-I-33 (Andre Klip \& Goran Sluiter eds., 2001).

113. Prosecutor v. Furundzija, Judgement, Case No. IT-95-17/1-T, T. Ch. II, 10 Dec. 1998, para. 57, International Criminal Tribunals for the Former Yugoslavia.

114. Bert Swart, Refusal of Extradition and the United Nations Model Treaty on Extradition, 1992 NETH. Y.B. INT'L L., 175, 182.

115. Id. at $182-83$.

116. Id. at 183 .

117. Bert Swart, Extradition, in INTERnational CRIMINAL LAW IN THE NETHERLANDS 85, 96 (Bert Swart \& Andre Klip eds., 1997). There are three approaches to determine whether the charged offence, even though criminal in both states, falls within the scope of the double criminality requirement. First, the act is chargeable in both states as a criminal offence regardless of whether it the individual can be prosecuted. Second, the act is chargeable and an individual may be prosecuted in both states. Third, the act is 
practically every extradition treaty as a general limit on what is an extraditable offence. ${ }^{118}$

Because the international criminal tribunals and member states have a cooperation relationship, the double criminality requirement is not a legitimate ground for a state to refuse an extradition request for two reasons - the principles of reciprocity and legality.

First, the requirement derives its "right of existence" in the first place from the principle of legality. This principle implies that a state can only invoke its own laws of criminal procedure when the conduct underlying the request for assistance is a crime in that state. It is unreasonable to suggest that a state should afford stricter standards of procedures to foreign crimes, especially in respect to compulsory measures such as arrest, than the procedures for domestic criminal crimes. ${ }^{119}$ Second, the requirement is based on the principle of reciprocity in international cooperation in criminal matters. When an act is criminal in both the requesting and requested state, it is possible for the requesting state to ask for assistance. ${ }^{120}$

Thus, as discussed above in Part II.C.2, states and the ICC have a cooperation relationship, which is not based on reciprocity. Thus, the double criminality requirement is not a legitimate ground to refuse an extradition request.

Regarding the most important underlying reason of the double criminality requirement, being the principle of legality, one should bear in mind the particular and limited subject matter jurisdiction of the court. Moreover, the crimes over which the ICC has jurisdiction are crimes that any state may exercise jurisdiction under general international law, or the universality principle. ${ }^{121}$ Further, a state may have treaty obligations that require it to penalise the crime under its domestic laws. Finally, states must faithfully implement the ICC crimes within their own criminal legislation based on the principle of complementarily. Thus,

chargeable, the individual may be prosecuted, and convicted in both states. BASSIOUNI, supra note 105, at 389-90.

118. See, e.g., European Convention, supra note 5, at 5; U.N. Model Treaty, supra note 5 , at 4 .

119. See KARL-Friedrich Nagel, Beweisaufnahme im AuSLand 98 (1988).

120. Id. at 219.

121. Cf. Harris \& Kushen, supra note 103, at 573. 
failure to do so can not be an acceptable basis for refusing assistance. $^{122}$

3. Immunity from Prosecution Under Domestic Law: Lapse of Time and Amnesty

Closely related to the double criminality requirement is the ability of a state to refuse to extradite an individual because the person is immune from domestic prosecution due to a grant of amnesty or lapse of time since the commission of the crime.

The lapse of a statute of limitation is a ground for refusal to surrender individuals in almost every extradition treaty. ${ }^{123}$ The rationale for this exception is that society's interest in prosecuting criminals diminishes over time. At issue is whether statutes of limitations apply to all offences, including international crimes. Under customary international law, states are obligated not to apply statutes of limitations to war crimes and crimes against humanity. ${ }^{124}$ Furthermore, crimes within the ICC's jurisdiction are not subject to any statute of limitations. Therefore, according to the ICC, the running of any statute of limitations is an illegitimate ground to refuse extradition.

The issue of amnesty is more complicated. Treaty practice has recognised amnesty as a ground to refuse extradition. ${ }^{125}$ It is unclear, however, if amnesty is a ground for refusal in the ICC. The issue of whether amnesty should be a ground for refusal touches upon the very purpose of the court, namely putting an end to impunity for international crimes. Strictly speaking, the issue of amnesty, like the defense of ne-bis-in-idem, appears to concern the

122. See id.; see also Swart, supra note 7, at 1682. 5.

1.23. See, e.g., European Convention, supra note 5, at 4; U.N. Model Treaty, supra note

124. Two treaties expressly state this obligation but they are not widely ratified. See Universal Convention on the Non-Applicability of Statutory Limitations to War Crimes and Crimes Against Humanity, G.A. Res. 3068 (XXVIII), Nov. 26, 1968, 754 U.N.T.S. 73; European Convention on the Non Applicability of Statutory Limitations to Crimes Against Humanity and War Crimes, Jan. 25, 1974, Europ. T.S. No. 82. The French Cour de Cassation explicitly mentions in the Barbie case that the prohibition on statutory limitations is now part of customary law. Fédération Nationale des Déportés et Internés Résistants et. al. v. Barbie, (1984) 78 I.L.R. 125, 135. Furthermore, the prohibition is codified in Article 29 of the ICC Statute and in Principle 6 of the Princeton Principles on Universal Jurisdiction.

125. See, e.g., U.N. Model Treaty, supra note 5, at 5. 
admissibility of the case. ${ }^{126}$ Neither the Statute nor the ICC regulations on admissibility address the question of amnesty. Arguably, crimes within the court's jurisdiction are so serious that amnesty could never constitute a bar to prosecution. ${ }^{127}$ On the other hand, the prosecution of individuals who have been granted amnesty by independent and impartial truth and reconciliation commissions may not serve the interests of justice and may have grave political consequences. Under the Statute, the prosecutor may decide not to start an investigation if an investigation would not serve the interests of justice. This could include amnesties granted by truth and reconciliation commissions. ${ }^{128}$ If the Prosecutor decides to start an investigation, however, a state may be confronted with a request for surrender. Such a request would require the state to violate amnesties granted under domestic law. It is possible that under such circumstances the court would find a legitimate ground for refusal, thereby exercising an indirect review of the prosecutor's decision to investigate. In determining whether amnesty is a legitimate ground for refusal, the court could look to the criteria under Article 20 (3) of the Statute, as guiding principles, relating to ne-bis-in-idem defenses.

\section{Non-Extradition/Surrender of Nationals}

In international extradition law, the non-extradition of nationals is a common ground for refusal, although civil law states follow this rule much more frequently than common law states. ${ }^{129}$ In certain civil law states, the rule of non-extradition of nationals has constitutional status. ${ }^{130}$ One can discern, however, a trend toward a more flexible interpretation of the non-extradition of nationals rule. For example, certain states may extradite their nationals on the condition that the nationals serve their sentences in the requested state. ${ }^{131}$

126. Amnesties, however, do not fall within the scope of Article 20 of the ICC Statute. See Dr. Christine Van den Wijngaert \& Tom Ongena, Ne bis in idem Principle, Including the Issue of Amnesty, in THE ROME STATUTE OF THE INTERNATIONAL CRIMINAL COURT: A COMMENTARY 726-27 (Antonio Cassese et al. eds., 2002).

127. See Gerhard Hafner et al., A Response to the American View as Presented by Ruth Wedgwood, 10 EUR. J. INT'L L. 109, 112 (1999).

128. Id.

129. See BASSIOUNI, supra note 105 , at 588.

130. E.g., F. R.YUgOSLAVIA CONST. art. 17; F.R.G. CONST. art. 16.

131. E.g., Dutch Extradition Act, supra note 80, art. 4(2). 
As previously mentioned, the issue of non-extradition of nationals was at the heart of the distinction between extradition and surrender. ${ }^{132}$ The majority of delegations, with good reason, prevented the insertion of a ground in the Statute that would allow a state to refuse the surrender of its nationals to the court. ${ }^{133}$ Indeed, it would undermine the court's ability to function effectively because every state party would have the possibility of preventing the surrender of its nationals by diligently prosecuting them internally. ${ }^{134}$

\section{Human Rights Related Grounds for Refusal}

Human rights play an increasingly important role in extradition. Many extradition treaties include a variety of grounds for refusal to extradite that seem inspired by the protection of human rights. These grounds may be concerned with certain particular inhuman treatment that awaits the requested person in the requesting state ${ }^{135}$ with the nature of the penalty in case of conviction, ${ }^{136}$ with the quality of the trial awaiting the arrested person, ${ }^{137}$ or with the quality of the trial constituting the basis for conviction and the requested extradition. ${ }^{138}$ Additionally, obligations under human rights treaties increasingly play a role in the extradition process, including the decision to grant extradition requests. Human rights impeding surrender would certainly amount to legitimate state concern because the ICC itself is bound to observe, on a priority basis, internationally protected human rights. ${ }^{139}$ Given the importance of the matter, the relationship of

132. See discussion supra Part II.A.

133. For an account of the debate, see Mochochoko, supra note 8, at 311-12.

134. See Swart, supra note 7, at 1683.

135. U.N. Model Treaty, supra note 5, at 5 (mentioning torture and inhuman or degrading treatment).

136. Id. (refusing extradition in case of the likely imposition of the death penalty); see European Convention, supra note 5, at 7.

137. U.N. Model Treaty, supra note 5, at 5 (prohibiting surrender if a person receives a trial in violation of the fundamental guarantees of Article 14 of the International Covenant on Civil and Political Rights). Extradition will also not be granted if it is requested for the purpose of discriminatory prosecution. See id.

138. The U.N. Model Treaty on Extradition prohibits extradition if the requested person has not received a fair trial pursuant to Article 14 of the ICCPR. If there has been a trial in absentia and the requested person is not entitled to a new trial after being extradited, then Article $3(\mathrm{~g})$ of the U.N. Model Treaty on Extradition applies. See id.

139. See ICC Statute, supra note 1, at 20. 
human rights on the surrender process will be examined in its own right in the next section.

\section{E. Conditions of Surrender: The Rule of Speciality}

According to Article 101 of the ICC Statute, the court shall not proceed against any person surrendered to the court for any conduct committed prior to surrender. The court may only institute proceedings for the conduct which forms the basis of the crimes for which that person has been surrendered. This rule, known in extradition law as the rule of speciality, cannot serve as a ground to refuse surrender. Rather, it imposes conditions on the legal consequences of surrender. The justification and purpose of the rule is to enforce the limitations and restrictions as set forth in extradition treaties. Otherwise, the limitations and restrictions laid down in extradition treaties would make little sense if the requesting state, after obtaining a person's surrender, could try the person for offences for which extradition has been refused or for offences for which extradition has not been requested. ${ }^{140}$

In light of its purpose in extradition law, it is puzzling why the rule of speciality has been incorporated in the ICC surrender regime. The ICC surrender regime is clearly distinct from extradition law because the extradition restrictions and limitations that the speciality rule purports to protect are not applicable..$^{141}$ In other words, why prohibit prosecution for other conduct if a state party would be under a practically absolute duty to surrender for that conduct as well? Taking account of the particular surrender duties, the ICTY Appeals Chamber has logically declared the rule of speciality not applicable. ${ }^{142}$

It is possible that the purpose of Article 101 is to protect the interests of nonparty states with respect to surrender pursuant to an ad hoc cooperation agreement or after the ad hoc acceptance of jurisdiction, as provided for in Article 12 (3) of the Statute. In these situations the duty of the nonparty state to surrender, if any, is confined to the conduct agreed upon in the ad hoc cooperation

140. Swart, supra note 7 , at 1698 .

141. Id. at 1699-1700; see also Peter Wilkitzki, Article 101 in COMMENTARY ON THE Rome STATUTE of THE INTERNational Criminal COURT: ObSERVERS' Notes, ARTICLE BY ARTICLE, supra note 3, at 1147-50.

142. Prosecutor v. Kovacevic, No. IT-97-24-AR73, para. 37, International Criminal Tribunal for the Former Yugoslavia, July 2, 1998, available at http://www.un.org/icty/ kovacevic/appeal/decision-e/80702ms3.htm (last visited Sept. 21, 2003). 
agreement or the crime for which the state accepted jurisdiction. The rule of speciality then serves to ensure that the court seeks the required consent for the prosecution of any other conduct. ${ }^{143}$

The second paragraph of Article 101 deals with requesting and obtaining a waiver of the speciality condition. The provision contains ambiguous language regarding whether state parties have a duty to waive the rule of specialty. The last sentence stipulates that "states Parties shall have the authority to provide a waiver to the court and should endeavour to do so." The words "endeavour to do so" imply that states parties have no obligation under the Statute to provide the waiver. A bar to extending the prosecution to other conduct is in clear contradiction with the mandatory nature of the surrender obligations. ${ }^{144}$

Article 101 applies only to prosecution by the court itself. It is surprisingly silent as to the re-extradition/surrender to a third state, to which the rule of speciality should apply. Instead, Rule 185 of the Draft Rules is controlling. According to Paragraph 1 of this provision, a released person may only be transferred to a third state for the purpose of prosecution with the consent of the surrendering state. ${ }^{145}$

\section{SURRENDER AND HUMAN RIGHTS}

National courts should serve as the first protectors of the individual rights of arrested persons, with the ICC serving an important supervisory role. However, there are other human rights dimensions to the surrender process, other than those discussed in Part V.D.v. above. The present Part of this article deals with two of them. The first is whether human rights violations after the surrender may, or even should, affect the

143. The rules of specialty in ad hoc cooperation agreements or ad hoc acceptance of jurisdiction could be part of an agreement between the court and the requested state. Swart, supra note 7, at 1700-01.

144. See Wilkitzki, supra note 141 , at 1155 (criticizing that this limitation is a step backward in relation to certain interstate extradition developments).

145. The ICTY and ICTR Rules contain a similar regulation. See ICTY AND ICTR RULES, supra note 3, at 233. Even in absence of this Rule, transfer of an individual whose indictment was withdrawn to a state for prosecution other than the state of arrest is unlawful according to the International Criminal Tribunal for Rwanda. But see Prosecutor v. Ntuyhaga, Decision on the Prosecutor's Motion to Withdraw the Indictment, Case No. ICTR-98-40-T, T. Ch. I, 18 March 1999, in ANNOTATEd LEAding CASES OF INTERNATIONAL CRIMINAL TRIBUNALS: THE INTERNATIONAL CRIMINAL TRIBUNAL FOR RWANDA1994-1999 ALC-II-106 (Andre Klip \& Goran Sluiter eds., 1999). 
surrender decision of the national court. The second issue is whether alternatives to surrender, namely abductions and forms of "disguised surrender" such as expulsions, are legal in light of international human rights laws.

\section{A. Treatment After Surrender}

Part V.D.v above alluded that the treatment of persons upon extradition, especially human rights violations, may compel a state to refuse the requested surrender. Under international human rights law, a state may be held liable if there are reasonable grounds to foresee that a serious violation of human rights will occur in a state and if the state, in spite of this likelihood, surrenders an individual to that state. ${ }^{146}$ This rule, as established in the Soering jurisprudence, also applies in principle to the ICC. ${ }^{147}$ As a result, the same two questions pertaining to extradition law must be addressed again. First, to what extent should a state abandon the traditional rule of inquiry and form an opinion as to the quality of the ICC proceedings? Second, which human rights violations within the ICC proceedings possibly constitute a bar to surrender?

\section{Rule of Non-Inquiry}

The non-inquiry rule prevents a judicial inquiry into the fairness of the judicial procedures and the penal conditions in the requesting state and is traditionally a strong tenet of extradition law. This rule is justified by the fact, inter alia, that judges are illequipped to examine foreign legal systems and that there is sovereign equality between states. This explains the reluctance to

146. This has been established by the supervisory bodies to both the ECHR and ICCPR in the cases of Soering and $\mathrm{Ng}$. Soering v. United Kingdom, Eur. Ct. of H.R., Judgement of 7 July 1989, Series A, Vol 161, para. 91; Ng v. Canada, Comm. No. 469/1991, 5 Nov. 1993, 1 INT'L HUM. RTS. REP. 161, 168 (1994). There are many articles and commentaries on these decisions and their important consequences. See SUSANNE ZÜHLKE \& JENS-CHRISTIAN PASTILLE, EXTRADITION AND THE EUROPEAN CONVENTION: SOERING REVISITED 749-84 (1999); Harmen G. van der Wilt \& Après Soering, The Relationship Between Extradition and Human Rights in the Legal Practice of Germany: The Netherlands and the United States, 42 NETH. INT'L L. REV. 1, 53 (1995); see generally Michael P. Shea, Expanding Judicial Scrutiny of Human Rights in Extradition Cases After Soering, 17 YALE J. OF INT'L L. 85 (1992).

147. This has been explicitly acknowledged by the Dutch government in the explanatory memorandum to the Dutch Cooperation Act and in the parliamentary debate on that act. Dutch Cooperation Act, supra note 80, at 7, 21. 
pass judgement on the quality of another state's criminal proceedings. ${ }^{148}$ Furthermore, the freely negotiated "cooperation" treaty reflects confidence in the foreign criminal justice system, a system that has been shaped through a long course of history. ${ }^{149}$ Hence, there would be no further need to question the requesting state's proceedings.

Perhaps more so than in a "horizontal" cooperation relationship, the ICTY and ICTR surrender practices demonstrate that national courts are inclined to maintain the rule of noninquiry in relation to international criminal tribunals. In Ntakirutimana, the accused challenged his transfer from the United States to the ICTR, inter alia, on the ground that "the ICTR is incapable of protecting his due process rights." "Tho majority of the U.S. Court of Appeals for the Fifth Circuit declined to consider this ground based on the rule of noninquiry. ${ }^{151}$

The rule of non-inquiry is an element of extradition law that should not be applied to surrender proceedings by analogy. As established above, the legal framework of the ICC, especially Article 97 of the Statute does not prevent states from reviewing requests for assistance. In addition, states are not prevented from passing judgment upon the general quality of the proceedings before the court. The court is an international organisation, but it is not subject to the human rights international supervisory mechanisms. ${ }^{152}$ Finally, the rule of non-inquiry is based on the assumption that the freely negotiated extradition treaty reflects confidence in the long-standing foreign criminal justice system. However, newer institutions such as the ICC must "earn" this confidence, in spite of the safeguards provided by the legal framework.

By far, the most compelling reason why the rule of noninquiry cannot be maintained lies in the human rights treaty obligations. The "Soering and $\mathrm{Ng}$ jurisprudence" does not

148. Shea, supra note 145 , at 93.

149. John Dugard \& Christine Van den Wijngaert, Reconciling Extradition with Human Rights, 92 AM. J. INT'L L.187, 189-90 (1989).

150. Ntakirutimana, v. Reno, 184 F.3d 419, 430 (5th Cir. 1999).

151. Id.

152. See André Klip, The Decrease of Protection under Human Rights Treaties in International Criminal Law, 68 INT'L REV. PENAL L. 291, 291-310 (1997) (criticizing how the ICC is not subject to the human rights international supervisory mechanisms). 
distinguish between human rights violations following extradition and other forms of transfer, such as expulsion, deportation, and surrender. ${ }^{153}$

\section{Possible Post-Surrender Human Rights Violations}

Exploring possible situations in which human rights might constitute a bar to surrender to the court is an academic exercise and very speculative. The ICC Statute appears to offer all the necessary safeguards during the pre-trial, trial, and sentence execution phases. ${ }^{154}$ It is an improvement from the ICTY and ICTR legal frameworks, which raised human rights concerns, especially during the sentencing phases. ${ }^{155}$

Given the foregoing, it may be difficult to imagine a situation in which the Soering jurisprudence may prevent surrender to the court. In fact, pursuant to the ECHR and ICCPR, state parties may only refuse to extradite, expel or surrender if the individual faces serious risks of human rights violations, such as cruel, inhuman or degrading treatment or punishment or flagrant fair trial violations. ${ }^{156}$ Therefore, it is not surprising that Naletilic's Complaint challenging his surrender from Croatia to the ICTY on the basis of the Soering jurisprudence was denied. ${ }^{157}$

153. This has also been acknowledged by the Dutch government. See Dutch Cooperation Act, supra note 80 . This has been explicitly acknowledged by the Dutch government in the explanatory memorandum to the Dutch Cooperation Act and in the course of the parliamentarian debate on that act. Id. at 7,21.

154. Note again the important gap-filling function of Article 21(3) of the Statute providing that the application and interpretation of the Statute and Rules must be consistent with internationally recognized human rights.

155. Upon ratifying the ICTR, Belgium included a reservation to its obligation to provide assistance and the enforcement of prison sentences in Rwanda where the rights of the detained persons are grossly violated. See Belgium Legislation, art. 13, 1996 Y.B. INT'L CRIM. TRIB. FOR THE FORMER YUGOSLAVIA 247. This provision arose mainly from the concern that the imposition of prison sentences would not meet the ECHR standards. This was not an imaginary concern considering that Article 26 of the ICTR Statute delegates an important role in enforcing prison sentences to Rwanda. See the legislative history of the Belgian implementing law, Sénat de Belgique, Session de 1995 1996, Projet de loi rélative à la coopération judiciaire avec le Tribunal international pour l'ex-Yougoslavie et le Tribunal international pour le Rwanda, 1-247/3, at 82. In practice, however, the ICTY and ICTR confirm that sentences are only enforced in states that are able to protect the basic rights of the detained person.

156. For an overview of the rights that obstruct extradition, see Dugard \& Van den Wijngaert, supra note 149, at 195-205.

157. Naletilic v. Croatia, supra note 68. The ICTY court ruled that "[it] offers all the necessary guarantees including those of impartiality and independence." 
It would go too far, however, to categorically exclude the possibility of the "Soering ground for refusal" in relation to international criminal proceedings. The proof of the pudding will, as always, be in the eating. The fact that a state has never withheld the surrender to the ICTY and ICTR on this ground does not mean that the proceedings of the latter are in full conformity with international human rights law. An incidental court ruling that may be at odds with human rights obligations, such as granting full anonymity to witnesses, ${ }^{158}$ is not the greatest concern. However, the same cannot be said of extremely long periods of pre-trial detention, which seem to be the rule rather than the exception with the ICTY and ICTR.

\section{B. Alternatives to Surrender: Abduction and "Disguised Surrender"}

The use of extradition alternatives to obtain custody of an alleged offender is highly controversial under international law. Alternative methods vary from the use of national immigration laws resulting in expulsion orders, "disguised extradition," to the brutal abduction of the wanted person from the territory of another state. ${ }^{159}$ Both disguised extradition and abductions are generally considered violations of the right to be free from arbitrary arrest and detention. ${ }^{160}$ Furthermore, abduction performed by state officials also violates the sovereignty of another state. Other national courts have accepted forms of disguised extradition and abduction as lawful. For example, the French Cour de Cassation in the Barbie case recognised disguised extradition as lawful in relation to crimes against humanity, where

158. See Prosecutor v. Tadic, Decision on the Prosecutor's Motion Requesting Protective Measures for Victims and Witnesses, Case No. IT-94-1-T, T. Ch. II (1995) in ANNOTATED LEADING CASES OF INTERNATIONAL CRIMINAL TRIBUNALS: THE INTERNATIONAL CRIMINAL TRIBUNALS FOR THE FORMER YUGOSLAVIA 1997-1999, ALC-I-55 (Andre Klip \& Goran Sluiter eds., 2001).

159. See BASSIOUNI, supra note 105, at 167-216, 217-94. For more detail see the Chapters on disguised extradition and abduction.

160. 'Disguised extradition' has been considered a violation of Article 5 ECHR. See Bozano v. France, 111 EUR. CT. OF H.R. (Ser. A) (1986). The Human Rights Committee has ruled on several occasions that cross-border abductions violate Article 9 of the ICCPR. See Francesco Cavallaro (alleged victim's legal representative) on behalf of Lilian Celiberti de Casariego v. Uruguay, Comm. No. 056/1979, Views of 29 July 1981, and Edgar A. Canon Garcia v. Ecuador, Comm. No. 319/1988, Views of 5 Nov. 1991. 
the "ordinary extradition rules do not apply." courts have failed to review these alternative methods in light of international human rights laws. ${ }^{162}$

The ICC, as any other court, may be tempted to benefit from an alternative means of obtaining custody over wanted persons, especially if they are accused of the most serious crimes. However, as an international body, it would be unthinkable for the court not to label certain forms of "disguised extradition" and abduction as unlawful human rights violations. However, case law from the ICTY and ICTR suggests that these courts do not hesitate with regards to this matter. ${ }^{163}$ The focus, therefore, should be on the consequences of "disguised extradition" and abductions. There has always been, and remains to be, abundant scholarly debate on the mala captus bene detentus doctrine. This doctrine enables a court to exercise jurisdiction even over an individual who has been unlawfully arrested or detained. ${ }^{164}$ Considerable reluctance to the release of wanted criminals is understandable, especially if they are accused of the most serious crimes. ${ }^{165}$ However, to preserve their own integrity and credibility as the guardians of human rights, with the aim of securing state cooperation for future trials, the ICTY and ICTR have rejected the doctrine of releasing criminals. As such the ICTY and ICTR, thereby acknowledge that

161. Fédération nationale des déportés et internés résistants et al. v. Barbie, (1984) 78 I.L.R. 125 (1984).

162. The most notorious example is the abduction of Alvarez-Machain from Mexico by individuals paid by U.S. law enforcement officials. United States v. Alvarez-Machain, 504 U.S. 655 (1992). Many commentaries have appeared within and outside the United states. See, e.g., Andrew L. Strauss, A Global Paradigm Shattered: The Jurisdictional Nihilism of the Supreme Court's Abduction Decision in Alvarez-Machain, 67 TEMP. L. REV. 1209 (1994); Analisa W. Scrimger, United states v. Alvarez-Machain: Forcible Abduction as an Acceptable Alternative Means of Gaining Jurisdiction, 7 TEMP. INT'L \& COMP. L. J. 369, 369-93 (1993).

163. See Prosecutor v. Mrkšic and others, Decision on the Motion for Release by the Accused Slavko Dokmanovic, Case No. 95-13a-PT, T.Ch. II (1997) in ANNOTATED LEADING Cases OF INTERNATIONAL CRIMINAL TRIBUnals: THE INTERNATIONAL CRIMINAL TRIBUNALS FOR THE FORMER YUGOSLAVIA 1997-1999, ALC-III-127 (Andre Klip \& Goran Sluiter eds., 2001). In this decision, the ICTY Trial Chamber, unlike the French Cour de Cassation in the Barbie case, did not make an exception for international crimes. Instead, the trial chamber recognized the unlawful character of certain methods of arrest and surrender.

164. In relation to the international criminal tribunals, see Michael P. Scharf, The Prosecutor v. Slavko Dokmanovic: Irregular Rendition and the ICTY, 11 LEIDEN J. INT'L L. 369 (1998); Lamb, supra note 69, at 167-244.

165. Scharf proposes an "Eichmann exception" for international crimes, which would make the mala captus bene detentus doctrine. Scharf, supra note 164, at 381 . 
an individual unlawfully arrested or detained shall be entitled to legal remedies. ${ }^{166}$ In the Nikolic decision, however, the Trial Chamber held that terminating the proceedings and the subsequent release of the accused, will only be an appropriate remedy if at least one, but preferably two, of the following conditions are met: (1) the Tribunal, especially the prosecutor, was involved in the unlawful arrest or detention; or (2) the unlawful arrest or detention is particularly egregious, such as serious mistreatment of the accused.

\section{CONCLUDING REMARKS}

Since the ICC is still far from truly operational, it is too early to judge whether the ICC surrender model is for efficacy and fairness reasons. However, the effectiveness of the proposed surrender scheme can be evaluated in two ways. In general, the ICC surrender regime is weaker than that of the ICTY and ICTR. With respect to surrender, one should mention that the weak points of the ICC Statute are the inflexible regulations on the issuance and transmission of requests, the insertion of the rule of speciality, the possibilities of postponing the provision of assistance, and the considerable role attributed to national law concerning the execution of requests. The difference in the way the law was established is the major reason why the ICC cooperation law is weaker. The ad hoc tribunals were established with limited mandate. As a result of their swift creation, the Tribunals, especially the judges themselves, created much of the law. Therefore, it comes as no surprise that the judges have opted for what is, in their eyes, the most effective cooperation regime. On the other hand, the establishment of the ICC by treaty triggered protracted rounds of negotiations, which soon revealed that participating states were not prepared to have the institution shape its own laws in any way. Since the shaping of the legal assistance regime was left to the participating states, the resulting compromise left the system significantly weaker on a number of points. ${ }^{167}$ From the perspective of the ad hoc tribunals, the ICC 70.

166. See Prosecutor v. Barayagwiza, supra note 56; Prosecutor v. Nikolic, supra note

167. One could also look at the ICC cooperation regime from a different perspective than that of the ad hoc tribunals. Compared to the recently created or proposed "internationalized tribunals" of Sierra Leone, Kosovo, East Timor and Cambodia, which were alluded to in, the introduction, the ICC is still a potentially powerful institution. 
cooperation model is disappointing. In addition, from the perspective of interstate cooperation in criminal matters, one cannot but be satisfied. Bearing in mind the likelihood that several states with no interest in a strong court participated in the negotiations, it is a significant achievement that the ICC surrender regime is still of predominantly hierarchical, vertical, nature. This is best demonstrated by the fact that the court itself, and only the court, determines the precise content of the duty to cooperate. Furthermore, traditional obstacles to surrender, which would make no sense in light of the particular nature and mandate of the ICC, have not found their way into the Statute.

Whether the model is fair, in that it adequately protects the rights of the requested person, the overall judgment can only be positive. Compared to the legal frameworks of the ICTR and ICTY, the ICC Statute constitutes an improvement. It makes the right to liberty and security of persons its primary concern by imposing clear obligations on the arresting and detaining state. The respect for this right in practice depends on the question of whether the arresting and detaining state and the ICC can mutually supervise their respective activities. Thus, the court should supervise the legality of the arrest and detention at the national level. The provision of effective legal remedies, if necessary, is an indispensable element of such supervision. Following the procedure envisaged by Article 97, the requested state must not be hesitant to review the surrender in light of human rights obligations and must submit to human rights considerations, if necessary, as an obstacle to surrender. It is to be hoped and expected, that this situation will not occur in practice.

These "internationalized tribunals" do not in any way enjoy the benefit of a vertical cooperation relationship and can only count on existing and applicable mechanisms of interstate legal assistance. As a result, a considerable amount of evidence-and a considerable number of suspects - could be beyond their reach. On the other hand, the "internationalized tribunals," with the exception of the Sierra Leone court, have the advantage of being integrated into a domestic legal order, enabling them to exercise enforcement powers over a certain territory. 
